Article

\title{
Soil Amendment with Raw Garlic Stalk: A Novel Strategy to Stimulate Growth and the Antioxidative Defense System in Monocropped Eggplant in the North of China
}

\author{
Muhammad Imran Ghani ${ }^{1}$, Ahmad Ali ${ }^{1}$, Muhammad Jawaad Atif ${ }^{1}$, Muhammad Ali ${ }^{1}$, \\ Bakht Amin ${ }^{1}$, Muhammad Anees ${ }^{2}$ and Zhihui Cheng ${ }^{1, *}$ \\ 1 College of Horticulture, Northwest A\&F University, Yangling 712100, China; \\ imran_pak@nwsuaf.edu.cn (M.I.G.); Ahmadhort87@nwafu.edu.cn (A.A.); \\ jawaadatif@nwafu.edu.cn (M.J.A.); muhammadali@nwsuaf.edu.cn (M.A.); \\ Bakhtamin96@nwafu.edu.cn (B.A.) \\ 2 Department of Microbiology, Kohat University of Science \& Technology, Kohat 26000, Pakistan; \\ dr.anees@kust.edu.pk \\ * Correspondence: chengzh@nwafu.edu.cn; Tel.: +86-29-8702613
}

Received: 24 January 2019; Accepted: 13 February 2019; Published: 15 February 2019

\begin{abstract}
Garlic (Allium Satioum L.) is a vegetable with known medicinal value. It is not only rich in nutrients, but also has the ability to combat different microbial infections. This is, however, the first study to investigate the effect of soil incorporation of the raw garlic stalk (RGS) on the growth and antioxidative defense system of eggplant. The experiments were conducted in pots using soil amendments of RGS in different ratios (RGS1 1:100; RGS2 3:100; RGS3 5:100 and control (CK) 0:100 of RGS: Soil $w / w$ ) and repeated in two consecutive years (2016 and 2017). A dose-dependent response of RGS amendment was observed in the growth and physiology of the eggplant. RGS1 and RGS2 significantly enhanced the plant height, root/shoot weight, stem diameter, leaf area, root length, root activity, pigment contents (chlorophyll a, chlorophyll b, and total chlorophyll), and photosynthetic parameters, but reduced intracellular $\mathrm{CO}_{2}(\mathrm{Ci})$ and enhanced fruit yield as compared with the respective controls. Consistently, RGS also enhanced activities of antioxidative enzymes of eggplant reported as a defense against stress indicators. RGS in its higher ratios (RGS3), however, caused a reduction in all of the growth and physiological parameters and increased stress indicators such as hydrogen peroxide $\left(\mathrm{H}_{2} \mathrm{O}_{2}\right)$ and malondialdehyde (MDA). Overall, RGS2 was found to be the most efficient for regulation of plant defense systems, reducing $\mathrm{H}_{2} \mathrm{O}_{2}$ and MDA and enhancing superoxide dismutase (SOD), peroxidase (POD), and phenylalanine ammonia-lyase (PAL) activity. It can be concluded that the appropriate ratio of RGS could efficiently promote plant growth and regulate the reactive oxygen-based plant defense system.
\end{abstract}

Keywords: raw garlic stalk; eggplant; antioxidants; plant growth; plant defense

\section{Introduction}

The incorporation of crop residue (CR) is an important component of a sustainable agricultural system. CR incorporation may be considered a potent source of available soil nutrients and organic matter for an intensive cultivation system [1]. Such organic inputs are useful in less fertile conditions, concomitantly inducing soil bio-recovery, promoting nutrient cycling, facilitating pest and disease management, and thereby affecting plant growth and productivity [2]. The soil biological properties, including plant growth, may be enhanced by $\mathrm{CR}$ incorporation [3]. CR also enhanced the availability of inorganic nitrogen in an intensive cultivation system $[4,5]$. 
Intensive protected cultivation is the prevalent type of vegetable production system in China, where continuous monocropping is a widespread agronomic practice, particularly under plastic tunnels [6]. Currently, China is the leading producer of eggplant, which is frequently grown under plastic greenhouses. However, such practices have led to decreased productivity due to monocropping and threaten the regional soil sustainability. The major issues faced in such systems include selective disease pressures and nutrient deficiencies [7]. Crops planted under a mono-cropping system are additionally prone to pests and pathogen attack [8].

F. oxysporum (Schlechtend) sp. Melongenae causes Fusarium wilt (Schlechtend) one of the serious diseases of eggplant. This soil-borne fungus blocks the xylem transport system, leading to the abrupt wilting and death of plants [9]. Moreover, the spores of F. oxysporum can withstand unfavorable conditions for an extended period and, therefore, alternative ecofriendly control strategies are required against this pathogen.

On the other hand, cumulative stresses may cause disturbance in the natural equilibrium of reactive oxygen species (ROS) and other stress indicators, leading to stunted plant growth [10]. Hydrogen peroxide $\left(\mathrm{H}_{2} \mathrm{O}_{2}\right)$ is an important non-radical ROS considered to be an indicator of biotic and abiotic stresses [11]. Furthermore, this molecule plays an important role in regulating different physiological processes including photorespiration, photosynthesis [12], growth, development, cell cycle [13], stomatal movement [14], and senescence [15]. Moreover, ROS serve dual functions in early signaling of plant defense, acting as a secondary messenger for modulating plant defense responses [16]. Extensive ROS production may cause serious consequences for plants, including membrane disability and damage to proteins and DNA as well as lipid peroxidation [17]. Peroxidases (POD) and catalases (CAT) have been reported to play a significant role in detoxifying $\mathrm{H}_{2} \mathrm{O}_{2}$ in peroxisomes in stress conditions due to salt, chilling, and Fusarium oxysporum (Schl.) infection [18].

The allelopathic crops and their components may offer potential ways to overcome the stresses related to monocropping of vegetables. Allium species (A. sativum L., A. cepa L., and A. fistulosum L.) have been reported to form isothiocyanates upon hydrolysis, possessing a broad spectrum of phytotoxic, antibiotic, nematicidal, insecticidal, and fungicidal effects [19]. For instance, garlic intercropping or rotation caused a significant increase in productivity and land use efficiency, leading to maximum economic return in different vegetables [6]. Similarly, it improved the soil biological and nutritional status and thereby improved the subsequent crop production [20]. In addition, garlic possesses antimicrobial activity, which enables it to protect nearby crops from soil-borne pathogens and pest attacks [21]. In this context, garlic may be considered a putative allelopathic crop with its different tissues including bulb, straw, roots, and their extracts having differential plant growth responses, as reported elsewhere [6].

Despite the above reports, there are very few scientific studies on the evaluation of the effects of raw garlic stalk (RGS) on the plant growth and resistance-related enzymes. Therefore, the present study was based on the use of RGS for alleviating continuous cropping obstacles and promoting crop growth in eggplant, which has never been considered before. This is the first report of the use of RGS amendment on eggplant cultivation under plastic tunnels and the impact of the amendment on plant growth, $\mathrm{H}_{2} \mathrm{O}_{2}$ concentration, MDA contents, and activities of resistance-related enzymes (SOD, POD, PPO, PAL) was evaluated. Different plant growth parameters measured in this study included the plant height, stem diameter, leaf area, root length, and root activity. In addition, the impact of RGS on the sporadic Fusarium disease incidence was also investigated.

\section{Materials and Methods}

\subsection{Experimental Site Description}

The experiments were conducted in pots at the Horticultural Experimental Station $\left(34^{\circ} 17^{\prime} \mathrm{N}\right.$, $108^{\circ} 4^{\prime}$ E) of Northwest A\&F University, Yangling, Shaanxi Province, China under a plastic tunnel. The 
highest and lowest temperatures recorded under plastic tunnel were approximately $50{ }^{\circ} \mathrm{C}$ in summer, and $-10^{\circ} \mathrm{C}$ in winter.

Sandy loam soil, classified as anthrosol according to the Food and Agriculture Organization (FAO), was collected from the field where eggplants had been planted continuously for the last four years. Eight kilograms of soil in the pots ( $30 \mathrm{~cm}$ diameter and $24 \mathrm{~cm}$ height) were used for the assays. The soil physicochemical properties measured before the experiment were $1.14 \mathrm{~g} \mathrm{~kg}^{-1}, 15.3 \mathrm{~g} \mathrm{~kg}^{-1}$, $26.87 \mathrm{~g} \mathrm{~kg}^{-1}, 0.91 \mathrm{~g} \mathrm{~kg}^{-1}$, and $6.87 \mathrm{~g} \mathrm{~kg}^{-1}$ of total nitrogen, organic carbon, organic matter, total phosphorus, and total potassium, respectively. The $\mathrm{pH}(7.75), \mathrm{EC}\left(383 \mu \mathrm{sm}^{-1}\right), \mathrm{C} / \mathrm{N}$ ratio (13.42), and available $\mathrm{N}, \mathrm{P}$, and $\mathrm{K}\left(60.3 \mathrm{mg} \mathrm{kg}^{-1}, 55.01 \mathrm{mg} \mathrm{kg}^{-1}\right.$, and $189.5 \mathrm{mg} \mathrm{kg}^{-1}$ of dry soil, respectively) were also measured.

\subsection{Preparation of Raw Garlic Stalk (RGS)}

RGS was collected from a garlic production field (cv. G064). The garlic stalks were harvested, dried under natural field conditions, homogenized into a powder ( $<2 \mathrm{~mm}$ sieves), and then stored in darkness at room temperature until use. The physicochemical properties of RGS were estimated, including $\mathrm{pH}(7.45)$, EC $\left(620 \mu \mathrm{sm}^{-1}\right)$, total nitrogen $(2.07 \mathrm{~g} / \mathrm{kg})$, organic carbon $(370.08 \mathrm{~g} / \mathrm{kg})$, organic matter $(639.25 \mathrm{~g} / \mathrm{kg}), \mathrm{C} / \mathrm{N}$ ratio $(179.13)$, total phosphorus $(12.87 \mathrm{~g} / \mathrm{kg})$, and total potassium $(0.19 \mathrm{~g} / \mathrm{kg})$.

\subsection{Plant Bioassays}

The seedlings of the eggplant (cv. Tai Kong Qie Wang) were raised in $35 \times 21$-cm plastic trays filled with commercial potting media. Three-week-old seedlings at the three-leaf stage were transplanted to the above prepared plastic pots containing soil material amended with RGS per $100 \mathrm{~g}$ of soil as follows: CK (without amendment), RGS1 (1 $\mathrm{g}$ of RGS), RGS2 (3 $\mathrm{g}$ of RGS), and RGS3 (5 $\mathrm{g}$ of RGS). All the treatments were replicated thrice and arranged according to completely randomized design (CRD), while each replication had 10 pots. Each pot was further amended with $10 \mathrm{~g}$ of organic fertilizer "Peng-Di-Xin" containing 30\% organic matter, $4 \% \mathrm{~N}+\mathrm{P}_{2} \mathrm{O}+\mathrm{K}_{2} \mathrm{O}, 20 \%$ humic acid, $2 \%$ trace elements, $5 \%$ organic sylvite, and $10 \mathrm{~g}$ of compound fertilizer $\left(\mathrm{N}-\mathrm{P}_{2} \mathrm{O}_{5}-\mathrm{K}_{2} \mathrm{O}\right.$ at 18:18:18). The experiments were repeated for two consecutive years from April 2016 to October 2017. Different morphological and physiological parameters of the plants were measured at four different developmental stages: i.e., 1st flowering (appearance of flowers on 1st branch), 1st fruiting (appearance of fruits on 1st branch), 2nd flowering (appearance of flowers on 2nd branch), and 2nd fruiting (appearance of fruits on 2nd branch) during both experimental years.

\subsection{Measurement of Growth Parameters Based on Morphology}

The plant height, stem diameter, leaf area, and root length were measured at 1st flowering, 1st fruiting, 2nd flowering, and 2nd fruiting. Measuring tape was used to take plant height and stem diameter was recorded by electronic Vernier calipers (Guanglu, Guilin, China). Leaf area was assessed according to the method described earlier [22]. For root length, plants were uprooted carefully to avoid any damage to roots, followed by washing with tap water and the root length being recorded by measuring tape. Fresh weights of root and shoot were also measured. For dry root and shoot weights, the tissues were oven-dried at $75^{\circ} \mathrm{C}$ until the weight was constant.

\subsection{Measurement of Root Activity}

The triphenyltetrazolium chloride (TTC) method was used to determine root activity following a protocol reported elsewhere with slight modifications [23]. Fresh roots $(0.2 \mathrm{~g})$ were immersed in $5 \mathrm{~mL}$ of $4 \%$ TTC and $5 \mathrm{~mL} \mathrm{Na}_{2} \mathrm{HPO}_{4}$ solution, and incubated at $37^{\circ} \mathrm{C}$ for $2 \mathrm{~h}$. Then, $10 \mathrm{~min}$ later, in order to stop the reaction, $2 \mathrm{~mL}$ of $\mathrm{H}_{2} \mathrm{SO}_{4}\left(1 \mathrm{moL} / \mathrm{L} \mathrm{H}_{2} \mathrm{SO}_{4}\right)$ was added. After the color became red, $6 \mathrm{~mL}$ of ethyl acetate were added in a volumetric flask to reach $10 \mathrm{~mL}$, the roots were ground, and Whatman filter paper was used to filter the mixture. The absorbance of extract was recorded using a wavelength $(485 \mathrm{~nm})$. 


$$
\text { TTC reduction strength }=\frac{\text { TTC reduction }}{\text { Fresh root weight } \times \text { hours of incubation } \times 10(\text { dilution factor })}
$$

\subsection{Determination of Physiological Indices}

\subsubsection{Chlorophyll and Carotenoid Contents}

Chlorophyll and carotenoid contents were analyzed with little modification from the method described elsewhere [24]. The fresh leaf sample $(0.5 \mathrm{~g})$ was homogenized and extracted with $10 \mathrm{~mL}$ of $80 \%$ acetone for $24 \mathrm{~h}$ until the leaves turned completely white. Afterwards, the concentrations of chlorophyll $\mathrm{a}$ and $\mathrm{b}$ were determined using a spectrophotometer (UV-3802, UNICO, MDN, WI, USA) at $663 \mathrm{~nm}$ and $645 \mathrm{~nm}$ wavelengths, respectively.

\subsubsection{Estimation of Plant Gas Exchange Parameters}

Photosynthetic parameters including photosynthetic rate $(\mathrm{Pn}), \mathrm{CO}_{2}$ assimilation $(\mathrm{Ci})$, transpiration rate (E), and stomatal conductance (Gs) were measured in the fully expanded third leaf from top using a portable photosynthetic system (LI-COR 6800XT, Lincoln, NE, USA). Measurements were taken on a sunny day before 11:00 a.m.

\subsection{Preparation of Leaf Extract for Malondialdehyde (MDA) and Antioxidative Enzymes Activity Assays}

Leaves were collected early in the morning (8:00 to 9:00 am) from the six random plants of each treatment from the upper parts at the four different developmental stages (1st flowering, 1st fruiting, 2nd flowering, and 2nd fruiting). Samples were packed in plastic bags and placed immediately in icebox. The samples were first washed with tap water and rinsed with distilled water. Leaves were then packed in aluminum foil and stored at $-80^{\circ} \mathrm{C}$ until use. Leaf samples $(0.5 \mathrm{~g})$ were crushed with a mortar and pestle in $2 \mathrm{~mL}$ of extraction buffer ( $0.05 \mathrm{M}$ phosphate buffer, $\mathrm{pH} 7.8)$, with $6 \mathrm{~mL}$ of the same buffer. The entire mixture was centrifuged at $10,000 \times g$ for $20 \mathrm{~min}$ at $4{ }^{\circ} \mathrm{C}$. MDA contents and enzymes activities were measured using this supernatant.

\subsubsection{Quantification of $\mathrm{H}_{2} \mathrm{O}_{2}$ and MDA Contents}

The quantities of $\mathrm{H}_{2} \mathrm{O}_{2}$ were estimated [25]. The leaves were frozen in liquid nitrogen, squeezed, and stored at $-80^{\circ} \mathrm{C}$. The squeezed sample $(150 \mathrm{mg})$ was ground with $1 \mathrm{~mL}$ of solution containing $\left(0.25 \mathrm{~mL}\right.$ TCA, $0.5 \mathrm{~mL} \mathrm{KI}(1 \mathrm{M})$, and $10 \mathrm{mM}(0.25 \mathrm{~mL})$ potassium phosphate buffer at $4{ }^{\circ} \mathrm{C}$ for $10 \mathrm{~min}$. In the meantime, a control was prepared with distilled $\mathrm{H}_{2} \mathrm{O}_{2}$ without potassium iodide. The prepared solution was kept in the dark and centrifuged at $12,000 \times \mathrm{g}$ for $15 \mathrm{~min}$ at $4{ }^{\circ} \mathrm{C}$. The supernatant $(200 \mu \mathrm{L})$ was put in UV-microplate wells and incubation was done $(20 \mathrm{~min})$ at room temperature. A calibration curve obtained with $\mathrm{H}_{2} \mathrm{O}_{2}$, the standard solution prepared in $0.1 \%$ TCA, was used for quantification. A Power Wave HT microplate spectrophotometer (BioTek, Winooski, VT, USA) with a built-in temperature incubator and shaker was used. To analyze the reaction, KC4 software (PowerWaveX ${ }^{\mathrm{TM}}$ Select and KC4 ${ }^{\mathrm{TM}}$; Biotek) was used.

The MDA content was determined using the thiobarbituric acid (TBA) reaction [26]. Two milliliters of extracted supernatant were mixed with $2 \mathrm{~mL}$ of $0.6 \%(w / v)$ TBA solution dissolved in $5 \%$ TCA $(v / v)$ and incubated in a water bath for $10 \mathrm{~min}$. The reaction mixture was then cooled to allow the flocculate to sediment. Spectrophotometric determination of MDA contents was done at wavelengths of 450 and $532 \mathrm{~nm}$, subtracted from the absorbance at $600 \mathrm{~nm}$. The MDA content was defined as the amount of the substance per gram fresh leaves $\left(\mathrm{nmol} \mathrm{g}^{-1} \mathrm{FW}\right)$.

\subsubsection{Antioxidative Enzyme Assays}

Total superoxide dismutase (SOD) activity was estimated using a previously described method with slight modifications [27]. The reaction mixture contained $1.5 \mathrm{~mL}$ of $0.05 \mathrm{M}$ phosphate buffer ( $\mathrm{pH} 7.8$ ), $0.3 \mathrm{~mL}$ of $0.1 \mathrm{mmol} \cdot \mathrm{L}^{-1}$ EDTA-Na, $0.3 \mathrm{~mL}$ of $0.13 \mathrm{~mol} \cdot \mathrm{L}^{-1}$ methionine, $0.3 \mathrm{~mL}$ of 
$0.75 \mathrm{mmol} \cdot \mathrm{L}^{-1}$ nitro blue tetrazolium (NBT), $0.3 \mathrm{~mL}$ of $0.02 \mathrm{mmol} \cdot \mathrm{L}^{-1}$ riboflavin, $0.05 \mathrm{~mL}$ enzymatic extract, and $0.25 \mathrm{~mL}$ distilled water in a total volume of $3 \mathrm{~mL}$. After exposing the solution to fluorescent light $\left(86.86 \mu \mathrm{mol} \cdot \mathrm{m}^{-2} \mathrm{~s}^{-1}\right)$ for $10-20 \mathrm{~min}$ (endpoint determined by the color of the reaction solution), the absorbance was recorded at the wavelength of $560 \mathrm{~nm}$. SOD activity was defined as $50 \%$ inhibition of the NBT reduction, caused by superoxidase generated from the reaction of photoreduction of riboflavin and oxygen. The total SOD activity was expressed in units per gram of fresh leaves ( $\left.\mu \mathrm{g}^{-1} \mathrm{FW}\right)$.

Peroxidase (POD) activity was determined by the Guaiacol method [28]. For this purpose, $50 \mathrm{~mL}$ of $0.05 \mathrm{M}$ phosphate buffer ( $\mathrm{pH} 7.8), 28 \mu \mathrm{L}$ guaiacol, and $19 \mu \mathrm{L}$ of $30 \% \mathrm{H}_{2} \mathrm{O}_{2}(v / v)$ were used to prepare the reaction mixture. The reaction mixture solution $(3.5 \mathrm{~mL})$ was then placed in a cuvette with a $1 \mathrm{~cm}$ path length. After adding $0.5 \mathrm{~mL}$ of the enzyme extract, an increase in absorbance was recorded at $470 \mathrm{~nm}$ wavelength over $3 \mathrm{~min}$ at 30-s intervals. The results were presented as OD 470 per min per gram of fresh leaves $\left(\mathrm{U} \mathrm{g}^{-1} \mathrm{~min}^{-1}\right)$.

Polyphenol oxidase (PPO) activity was measured by the increase in colored oxidation products during the first $3 \mathrm{~min}$ of the reaction [29]. After heating at $37^{\circ} \mathrm{C}$ for $10 \mathrm{~min}$, a mixture of $1.5 \mathrm{~mL} 0.05 \mathrm{M}$ phosphate buffer (pH 7.8) and $1.0 \mathrm{~mL} 0.1 \mathrm{~mol} \mathrm{~L}^{-1}$ catechol was placed in a cuvette with a $1 \mathrm{~cm}$ length of path. Soon after the addition of $0.5 \mathrm{~mL}$ enzyme extract to initiate the reaction, the activity was measured at $410 \mathrm{~nm}$ every $30 \mathrm{~s}$ for $3 \mathrm{~min}$. One unit of PPO was defined as the amount of enzyme that produced a change in absorbance of $0.001 \mathrm{~min}^{-1}$. PAL activity was assayed using the previously describe procedure [27]. A 4-mL mixture containing $2.7 \mathrm{~mL}$ of $0.05 \mathrm{M}$ phosphate buffer (pH 7.8), $1 \mathrm{~mL}$ of $0.02 \mathrm{~mol} \mathrm{~L}^{-1} \mathrm{~L}$-phenylalanine, and $0.3 \mathrm{~mL}$ enzyme extract was incubated at $30^{\circ} \mathrm{C}$ for $60 \mathrm{~min}$; the reaction was then terminated by the addition of $0.2 \mathrm{~mL}^{-1}$ of $6 \mathrm{~mol} \mathrm{~L}^{-1} \mathrm{HCl}$. The spectrophotometer was used to take measurements at $290 \mathrm{~nm}$ wavelength. One unit of PAL was defined as the amount needed to produce a change in absorbance of 0.01 per hour at $290 \mathrm{~nm}$, which was equivalent to $1 \mathrm{~mL}$ of reaction solution forming $1 \mu \mathrm{g}$ transcinnamic acid.

\subsection{Estimation of the Fusarium wilt Disease Control Index and Eggplant Yield}

The disease was evaluated daily according to a method proposed earlier [30]. The disease severity index was ranked on a $0-4$ scale ( $1:<25 \%$ wilted leaves, 2 : $25-50 \%$ wilted leaves, $3: 50-75 \%$ wilted leaves and 4: 75-100\%) wilted leaves. For the disease index measurement, the following formula was used:

$$
\text { Disease index }=\frac{\sum \text { Disease grade } \times \text { Number of plants in each grade }}{\text { Total number of plants } \times \text { highest disease grade }} \times 100
$$

The disease incidence was calculated by the following formula:

$$
\text { Disease incidence }=\frac{\text { Number of infected plants }}{\text { Total number of plants }} \times 100
$$

Eggplant yield was recorded as the total edible fruits harvested (gram per plant) during the years 2016 and 2017.

\subsection{Statistical Analysis}

The significant variance among treatments were tested by two-way analysis of variance (ANOVA) as a $4 \times 2$ (treatment $\times$ year) factorial arrangement for the trial, and mean separations among treatments were examined using Fisher's least significant difference (LSD) test at $p<0.05$. Statistical analyses were performed by SPSS 19.0 (SPSS Inc., Chicago, IL, USA).

\section{Results}

\subsection{Effect of RGS on Morphological Growth Parameters and Root Activity}

Different ratios of RGS had a significant effect on the plant height (Figure 1A,D). The height increased rapidly from 1st to 2nd flowering during both experimental years, but slow growth was 
observed at later stages. RGS1 and RGS2 showed a significant promoting effect and the maximum plant height observed was at the 2nd fruiting stage, which was $31 \%$ and $46 \%$ higher than the control treatments (CK) in 2016 and 2017, respectively. The application of the higher ratio (RGS3) showed an inhibitory effect on the plant height and a $15 \%$ and $9 \%$ reduction as compared to control treatment was observed in 2016 and 2017, respectively (Figure 1A,D).

The stem diameter steadily increased in both experimental years. A trend of rapid increase was observed from 1st fruiting to 2nd fruiting stage and after that no significant increase was observed (Figure 1E,H). The stem was the thickest in RGS2 at the 2nd fruiting stage, being 21\% (2016) and 23\% (2017) higher than the control CK. The treatment RGS3 showed an inhibitory effect and caused a $6 \%$ (2016) and 3\% (2017) reduction in stem diameter at the same growth stage (Figure 1E,H).
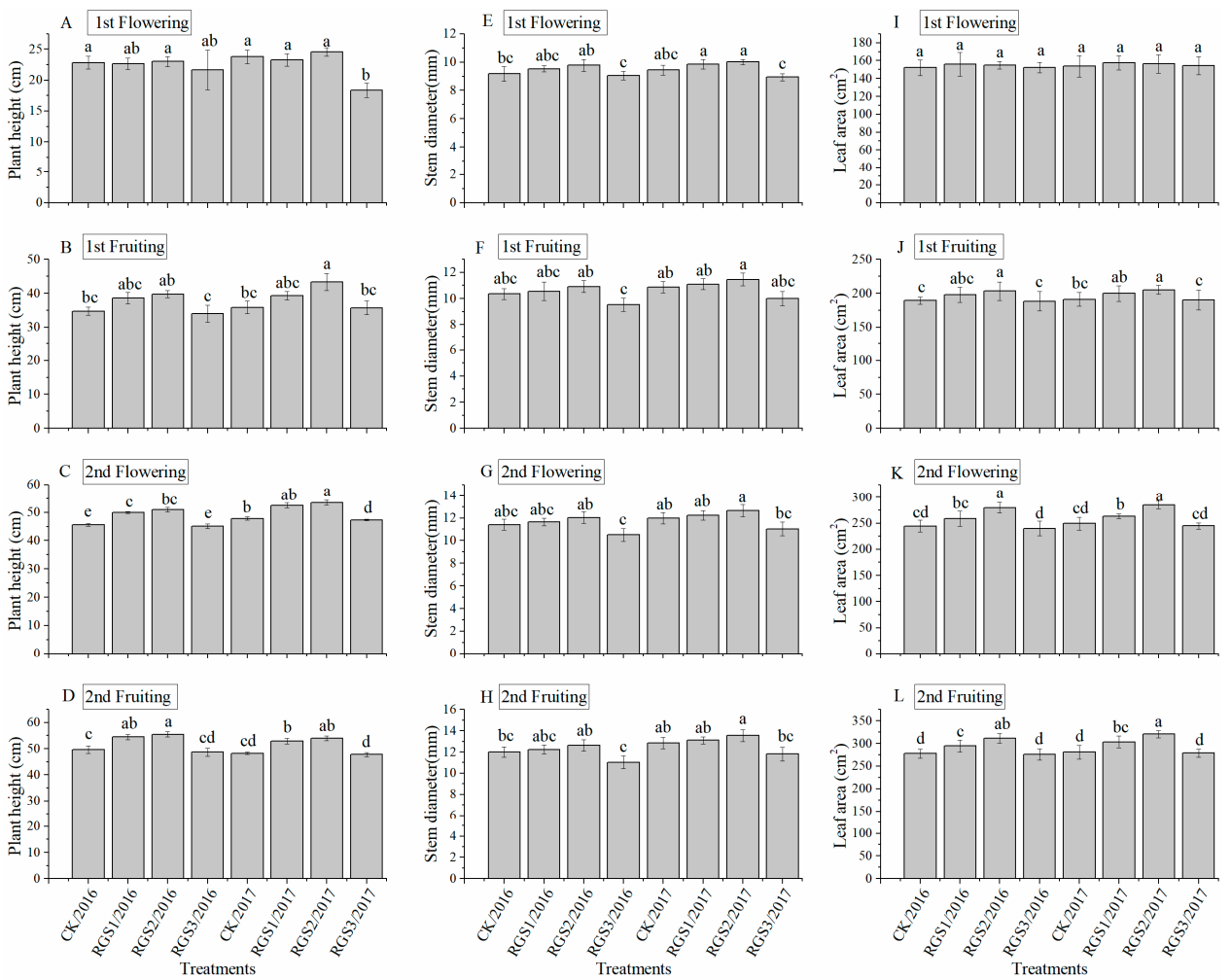

Figure 1. Effect of amendment with raw garlic stalk on various growth and development parameters of eggplant recorded at different growth stage of eggplant. Plant height (A) 1st flowering, (B) 1st fruiting, (C) 2nd flowering and (D) 2nd fruiting, stem diameter (E) 1st flowering, (F) 1st fruiting, (G) 2nd flowering and (H) 2nd fruiting, leaf area (I) 1st flowering, (J) 1st fruiting, (K) 2nd flowering and (L) 2nd fruiting. The error bars represent standard error of the means $(n=3)$. Different letters between treatments at different sampling stages show significant difference at $p<0.05$ level (ANOVA and LSD).

The leaf area increased with the age of the plant. Plants showing a similar trend were compared to those observed for stem diameter. Maximum leaf area was observed in the treatment of RGS2 and minimum in the case of RGS3 (Figure 1I,J).

The impact of RGS on root length is given in Figure 2. RGS1 and RGS2 treatments significantly increased the root length, whereas RGS3 significantly decreased the root length as compared to the respective controls (Figure 2).

The effect of tested RGS treatments on shoot and root, fresh and dry weights is shown in Figure 3. The RGS1 and RGS2 treatments significantly enhanced the shoot fresh and dry weights in eggplant as compared to the control CK. While RGS1 had no significant effect on shoot fresh weight compared with CK, a prominent effect of RGS2 was observed on shoot dry weight, which was $30 \%$ and $57 \%$ 
higher than the control CK during 2016 and 2017, respectively. An inhibitory effect was noticed in the case of RGS3, with a 1\% and 2\% reduction in fresh and 4\% and 7\% reduction in dry weights in 2016 and 2017, respectively (Figure 3A,B).

The root fresh and dry weights increased after treatment with RGS1 and RGS2 in both year trials, but the effect was more obvious in 2017 (Figure 3C,D). Highest root fresh and dry weight was obtained upon treatment with RGS2, which was 57\% and 36\% higher in 2016, and 59\% and 62\% higher in 2017 as compared with $\mathrm{CK}$, respectively (Figure 3C,D).

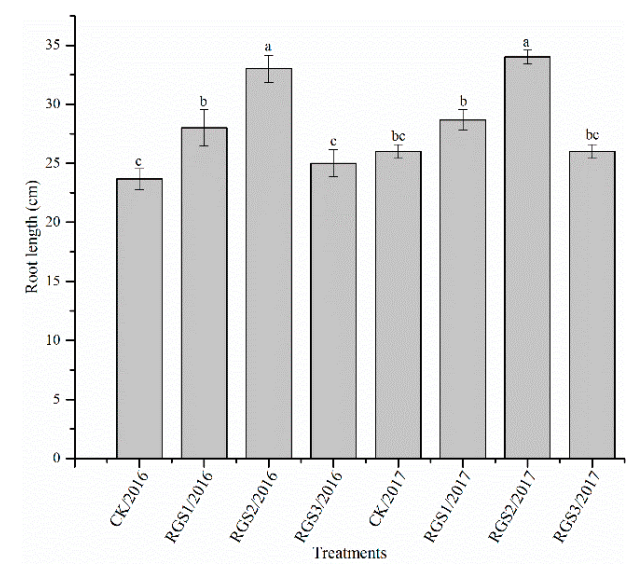

Figure 2. Effect of amendment with raw garlic stalk on root length of eggplant. The error bars represent standard error of the means $(n=3)$. The error bars represent standard of the means. Different letters between treatments at different sampling stages show significant difference at $p<0.05$ level (ANOVA and LSD).
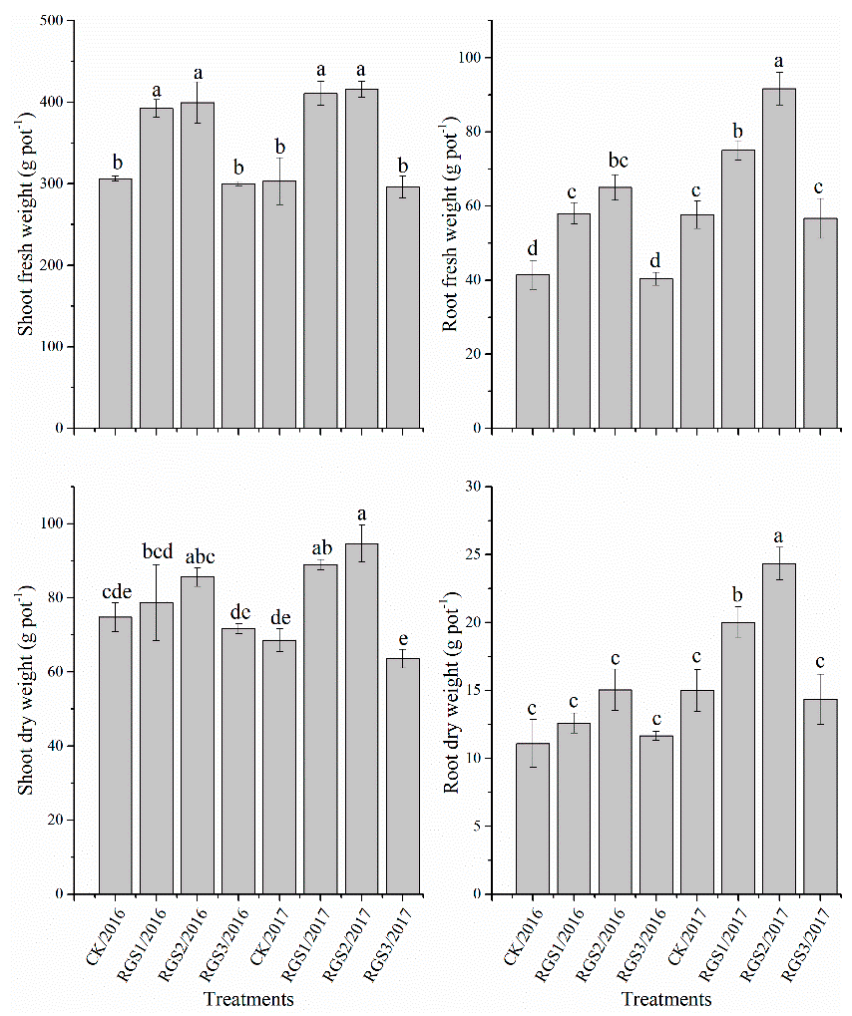

Figure 3. Effect of amendment with raw garlic stalk on shoot fresh and dry weight. Shoot fresh and dry weight $(\mathbf{A}, \mathbf{B})$. Root fresh and dry weight $(\mathbf{C}, \mathbf{D})$. The error bars represent standard error of the means $(n=3)$. Different letters between treatments at different sampling stages show significant difference at $p<0.05$ level (ANOVA and LSD). 
The root activity of the eggplant in two different years is presented in Figure 4. A significant increase in root activity was observed in the case of RGS1 and RGS2, i.e., 34\% and 35\%, respectively, in 2016 and $48 \%$ and 50\%, respectively, in 2017, whereas the higher concentration of RGS3 significantly decreased the root activity by $3 \%$ and $4 \%$ in 2016 and 2017, respectively (Figure 4).

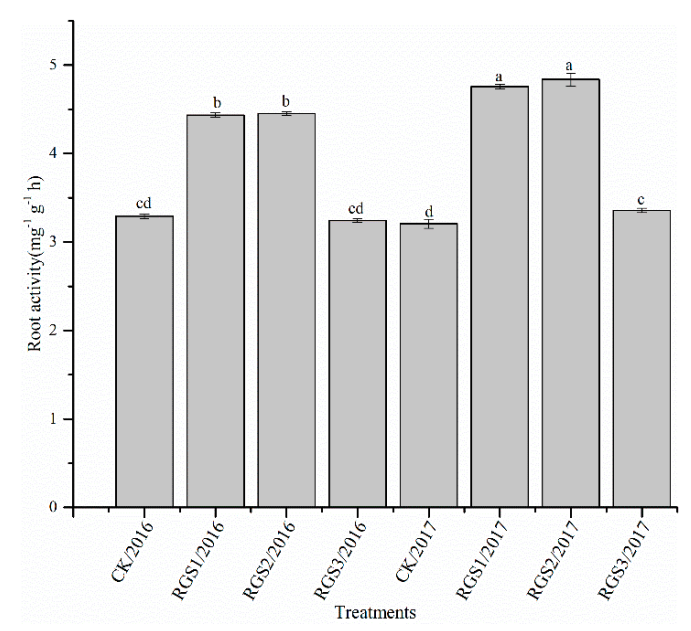

Figure 4. Effect of amendment with raw garlic stalk on root activity of eggplant. The error bars represent standard error of the means $(n=3)$. Different letters between treatments at different sampling stages show significant difference at $p<0.05$ level (ANOVA and LSD).

\subsection{Effect of RGS on Chlorophyll Contents and Carotenoids in Leaves}

The chlorophyll pigments showed variable responses towards the different amount of RGS applied. For instance, chlorophyll pigments significantly increased under RGS1 and RGS2 treatments, whereas they decreased under RGS3 (Table 1). With respect to the growing stages, higher chlorophyll a content was observed in RGS1 and RGS2 at 1st flowering and 1st fruiting stage than that of 2nd flowering and 2nd fruiting stages of both years, respectively. At the 1st flowering stage, chlorophyll a in RGS1 and RGS2 was 30 and 40\% higher as compared to the control in 2016 and it showed a 32\% and $35 \%$ increase in chlorophyll a in 2017. At the 1st fruiting stage, it was $20 \%$ and $31 \%$ higher in 2016. A similar trend was observed in 2017, while RGS3 showed a decreasing trend in all sampling stages compared to the CK. In chlorophyll a, the interaction between treatment and year showed a significant difference at the 1st and 2nd flowering stages, whereas the 1st and 2nd fruiting stages showed non-significant differences (Table 1). A significant difference was observed in chlorophyll b at all stages except the 2nd fruiting stage. Higher chlorophyll b content was observed in RGS1 and RGS2 at the 1 st flowering stage, $9 \%$ and 39\% higher as compared to the control in 2016, whereas in 2017 it was $22 \%$ and $57 \%$ higher as compared to control. The interaction between treatment and year was non-significant at all stages (Table 2).

Moreover, total chlorophyll contents were higher at the 1st flowering and 1st fruiting stages, being 24\% and 41\% higher in RGS1 and RGS2 in 2016, at 1st flowering and a similar trend was found in 2017. Overall, the total chlorophyll increased in RGS1 and RGS2 at all sampling stages respective to the control. In contrast, RGS3 showed inhibitory effect in all sampling stages. Interaction between treatment and year showed significant difference in the 1st flowering and 2nd flowering stages, whereas non-significant differences were observed during the 1st and 2nd fruiting (Table 3). Carotenoids were significantly higher during the 1st flowering stage in RGS1 and RGS2, by 10\% and $20 \%$ in 2016 and $36 \%$ and $26 \%$ in 2017 respective to the control. In contrast, RGS3 showed an inhibitory effect in all the sampling stages. We observed a significant difference among treatments at all stages in carotenoids, while year and treatment interaction have significant differences at all stages except the 2nd fruiting stage (Table 4). 
Table 1. Effect of amendment with raw garlic stalk on Chlorophyll a content in eggplant leaves.

\begin{tabular}{|c|c|c|c|c|c|c|c|c|c|c|c|c|}
\hline \multicolumn{13}{|c|}{ Chlorophyll a (mg g $\left.{ }^{-1} \mathrm{FW}\right)$} \\
\hline \multirow{2}{*}{ Treatment } & \multicolumn{3}{|c|}{ 1st Flowering } & \multicolumn{3}{|c|}{ 1st Fruiting } & \multicolumn{3}{|c|}{ 2nd Flowering } & \multicolumn{3}{|c|}{ 2nd Fruiting } \\
\hline & 2016 & 2017 & Means & 2016 & 2017 & Means & 2016 & 2017 & Means & 2016 & 2017 & Means \\
\hline CK & $13.71^{\mathrm{e}}$ & $15.46^{\mathrm{d}}$ & $14.59^{\mathrm{c}}$ & 12.94 & 10.76 & $11.85^{c}$ & $10.68^{\mathrm{d}}$ & $9.96^{\mathrm{e}}$ & $10.32^{c}$ & 9.49 & 8.58 & 9.03 \\
\hline RGS1 & $17.87^{\mathrm{c}}$ & $20.51^{a b}$ & $19.19^{\mathrm{b}}$ & 15.59 & 13.34 & $14.46^{\mathrm{b}}$ & $11.01^{\mathrm{cd}}$ & $11.55^{\mathrm{c}}$ & $11.28^{\mathrm{b}}$ & 10.36 & 9.97 & 10.16 \\
\hline RGS2 & $19.55^{b}$ & $20.88^{a}$ & $20.22^{a}$ & 17.06 & 14.19 & $15.62^{\mathrm{a}}$ & $13.83^{\mathrm{a}}$ & $12.37^{c}$ & $13.10^{\mathrm{a}}$ & 11.49 & 10.42 & 10.96 \\
\hline RGS3 & $12.97^{\mathrm{e}}$ & $13.08^{\mathrm{e}}$ & $13.02^{\mathrm{d}}$ & 11.85 & 8.99 & $10.42^{\mathrm{d}}$ & $9.81^{\mathrm{e}}$ & $9.15^{\mathrm{f}}$ & $9.48^{\mathrm{d}}$ & 8.48 & 7.80 & 8.14 \\
\hline Year means & 16.03 & 17.48 & & 14.36 & 11.82 & & 11.33 & 10.76 & & 9.96 & 9.19 & \\
\hline LSD-test & $\underset{* * *}{\text { Treatment }}$ & Year & $\underset{* *}{\text { Interaction }}$ & $\underset{* * *}{\text { Treatment }}$ & Year & $\begin{array}{c}\text { Interaction } \\
\text { NS }\end{array}$ & $\underset{* * * *}{\text { Treatment }}$ & Year & $\underset{* * *}{\text { Interaction }}$ & $\begin{array}{c}\text { Treatment } \\
\text { NS }\end{array}$ & $\underset{* * *}{\text { Year }}$ & $\begin{array}{c}\text { Interaction } \\
\text { NS }\end{array}$ \\
\hline
\end{tabular}

Different letters indicate significant differences between means within columns at $p<0.05$ (ANOVA and LSD). ${ }^{* *} p<0.011^{* * *} p<0.001$. NS: Non-significant.

Table 2. Effect of amendment with raw garlic stalk on Chlorophyll b content in eggplant leaves.

\begin{tabular}{|c|c|c|c|c|c|c|c|c|c|c|c|c|}
\hline \multicolumn{13}{|c|}{ Chlorophyll b (mg g $\left.{ }^{-1} \mathrm{FW}\right)$} \\
\hline \multirow{2}{*}{ Treatment } & \multicolumn{3}{|c|}{ 1st Flowering } & \multicolumn{3}{|c|}{ 1st Fruiting } & \multicolumn{3}{|c|}{ 2nd Flowering } & \multicolumn{3}{|c|}{ 2nd Fruiting } \\
\hline & 2016 & 2017 & Means & 2016 & 2017 & Means & 2016 & 2017 & Means & 2016 & 2017 & Means \\
\hline CK & 5.54 & 4.70 & $5.12^{c}$ & 3.44 & 3.79 & $3.61^{b}$ & 3.57 & 2.44 & $3.00 \mathrm{bc}$ & 2.37 & 2.90 & 2.64 \\
\hline RGS1 & 6.06 & 5.78 & $5.92^{b}$ & 4.23 & 4.45 & $4.34^{\mathrm{a}}$ & 3.76 & 2.67 & $3.21 \mathrm{ab}$ & 2.43 & 2.96 & 2.69 \\
\hline RGS2 & 7.74 & 7.38 & $7.57^{\mathrm{a}}$ & 4.23 & 4.35 & $4.29^{\mathrm{a}}$ & 3.87 & 2.77 & $3.32^{\mathrm{a}}$ & 2.58 & 3.27 & 2.93 \\
\hline RGS3 & 5.36 & 4.64 & $5.00^{c}$ & 3.39 & 3.55 & $3.47^{b}$ & 3.53 & 2.15 & $2.83^{\mathrm{c}}$ & 2.67 & 2.87 & 2.57 \\
\hline Year means & 6.18 & 5.62 & & 3.82 & 4.03 & & 3.68 & 2.51 & & 2.41 & 3.00 & \\
\hline LSD-test & $\underset{* * *}{\text { Treatment }}$ & $\underset{* *}{\text { Year }}$ & $\begin{array}{c}\text { Interaction } \\
\quad \text { NS }\end{array}$ & $\underset{* * *}{\text { Treatment }}$ & $\underset{* *}{\text { Year }}$ & $\begin{array}{c}\text { Interaction } \\
\text { NS }\end{array}$ & $\underset{* *}{\text { Treatment }}$ & Year & $\begin{array}{c}\text { Interaction } \\
\text { NS }\end{array}$ & $\begin{array}{c}\text { Treatment } \\
\text { NS }\end{array}$ & $\underset{* * *}{\text { Year }}$ & $\begin{array}{c}\text { Interaction } \\
\text { NS }\end{array}$ \\
\hline
\end{tabular}

Different letters indicate significant differences between means within columns at $p<0.05$ (ANOVA and LSD) ${ }^{* *} p<0.01,{ }^{* * *} p<0.001$. NS: Non-significant. 
Table 3. Effect of amendment with raw garlic stalk on Chlorophyll ab content in eggplant aboveground biomass.

\begin{tabular}{|c|c|c|c|c|c|c|c|c|c|c|c|c|}
\hline \multicolumn{13}{|c|}{ Chlorophyll ab (mg g $\left.{ }^{-1} \mathrm{FW}\right)$} \\
\hline \multirow{2}{*}{ Treatment } & \multicolumn{3}{|c|}{ 1st Flowering } & \multicolumn{3}{|c|}{ 1st Fruiting } & \multicolumn{3}{|c|}{ 2nd Flowering } & \multicolumn{3}{|c|}{ 2nd Fruiting } \\
\hline & 2016 & 2017 & Means & 2016 & Treatment & 2016 & 2017 & Means & 2016 & Treatment & 2016 & 2017 \\
\hline CK & $19.26^{\text {de }}$ & $20.17^{d}$ & $19.71^{c}$ & 16.38 & 14.55 & $15.6^{c}$ & $14.25^{c}$ & $12.39^{\mathrm{e}}$ & $13.32^{c}$ & 11.86 & 11.48 & $11.67^{\mathrm{c}}$ \\
\hline RGS1 & $23.94^{c}$ & $26.29^{b}$ & $25.11^{b}$ & 19.83 & 17.78 & $18.80^{\mathrm{b}}$ & $14.77^{b c}$ & $14.22^{\mathrm{c}}$ & $14.49^{\mathrm{b}}$ & 12.79 & 12.93 & $12.86^{\mathrm{b}}$ \\
\hline RGS2 & $27.30^{\mathrm{ab}}$ & $28.27^{\mathrm{a}}$ & $27.78^{a}$ & 21.29 & 18.55 & $19.91^{\mathrm{a}}$ & $17.70^{\mathrm{a}}$ & $15.13^{b}$ & $16.42^{\mathrm{a}}$ & 14.08 & 13.69 & $13.88^{\mathrm{a}}$ \\
\hline RGS3 & $18.3^{\text {ef }}$ & $17.72^{\mathrm{f}}$ & $18.02^{\mathrm{d}}$ & 15.24 & 12.55 & $13.89^{\mathrm{d}}$ & $1.33^{\mathrm{d}}$ & $11.30^{\mathrm{f}}$ & $12.31^{\mathrm{d}}$ & 10.75 & 10.67 & $10.71^{\mathrm{d}}$ \\
\hline Year means & 22.21 & 2.11 & & 18.18 & 15.86 & & 15.02 & 13.26 & & 12.36 & 12.19 & \\
\hline LSD-test & $\underset{* * *}{\text { Treatment }}$ & $\underset{* *}{\text { Year }}$ & $\underset{*}{\text { Interaction }}$ & $\underset{* * *}{\text { Treatment }}$ & $\underset{* * *}{\text { Year }}$ & $\begin{array}{c}\text { Interaction } \\
\text { NS }\end{array}$ & $\underset{* * *}{\text { Treatment }}$ & $\underset{* * *}{\text { Year }}$ & $\underset{* *}{\text { Interaction }}$ & $\underset{* * *}{\text { Treatment }}$ & $\begin{array}{l}\text { Year } \\
\text { NS }\end{array}$ & $\begin{array}{c}\text { Interaction } \\
\text { NS }\end{array}$ \\
\hline
\end{tabular}

Different letters indicate significant differences between means within columns at $p<0.05$ (ANOVA and LSD). ${ }^{*} p<0.05,{ }^{* *} p<0.01,{ }^{* * *} p<0.001$. NS: Non-significant.

Table 4. Effect of amendment with raw garlic stalk on carotenoids.

\begin{tabular}{|c|c|c|c|c|c|c|c|c|c|c|c|c|}
\hline \multicolumn{13}{|c|}{ Carotenoids $\left(\mathrm{mg} \mathrm{g}^{-1} \mathrm{FW}\right)$} \\
\hline \multirow{2}{*}{ Treatment } & \multicolumn{3}{|c|}{ 1st Flowering } & \multicolumn{3}{|c|}{ 1st Fruiting } & \multicolumn{3}{|c|}{ 2nd Flowering } & \multicolumn{3}{|c|}{ 2nd Fruiting } \\
\hline & 2016 & 2017 & Means & 2016 & Treatment & 2016 & 2017 & Means & 2016 & Treatment & 2016 & 2017 \\
\hline $\mathrm{CK}$ & $3.36^{\mathrm{e}}$ & $4.69^{c}$ & $4.02^{b}$ & $2.92^{c}$ & $3.05^{\mathrm{c}}$ & $2.99^{b}$ & $1.36^{\mathrm{d}}$ & $3.51^{\mathrm{b}}$ & $2.43^{b}$ & 1.71 & 2.21 & $1.97^{b}$ \\
\hline RGS1 & $3.73 \mathrm{de}$ & $6.39^{\mathrm{a}}$ & $5.06^{\mathrm{a}}$ & $4.78^{\mathrm{a}}$ & $3.89^{b}$ & $4.33^{\mathrm{a}}$ & $1.57^{\mathrm{d}}$ & $3.91^{\mathrm{b}}$ & $2.74^{\mathrm{a}}$ & 2.01 & 2.53 & $2.27^{\mathrm{a}}$ \\
\hline RGS2 & $4.04^{\mathrm{d}}$ & $5.92^{b}$ & $4.98^{\mathrm{a}}$ & $3.92^{b}$ & $4.29 \mathrm{ab}$ & $4.10^{\mathrm{a}}$ & $1.63^{\mathrm{d}}$ & $4.34^{\mathrm{a}}$ & $2.99^{\mathrm{a}}$ & 2.05 & 2.49 & $2.27^{\mathrm{a}}$ \\
\hline RGS3 & $3.34 \mathrm{e}$ & $3.70 \mathrm{de}$ & $3.52^{\mathrm{c}}$ & $2.31^{\mathrm{d}}$ & $2.40^{\mathrm{d}}$ & $2.36^{\mathrm{c}}$ & $1.28^{\mathrm{d}}$ & $3.02^{c}$ & $2.15^{b}$ & 1.29 & 2.16 & $1.73^{c}$ \\
\hline Year means & 3.62 & 5.18 & & 3.48 & 3.41 & & 1.46 & 3.69 & & 1.77 & 2.35 & \\
\hline LSD-test & $\underset{* * *}{\text { Treatment }}$ & Year & $\underset{* * *}{\text { Interaction }}$ & $\underset{* * *}{\text { Treatment }}$ & $\begin{array}{l}\text { Year } \\
\text { NS }\end{array}$ & $\underset{* *}{\text { Interaction }}$ & $\underset{* * *}{\text { Treatment }}$ & $\underset{* * *}{\text { Year }}$ & $\underset{*}{\text { Interaction }}$ & $\underset{* * *}{\text { Treatment }}$ & $\underset{* * *}{\text { Year }}$ & $\begin{array}{c}\text { Interaction } \\
\text { NS }\end{array}$ \\
\hline
\end{tabular}




\subsection{Effect of RGS on Gas Exchange Parameters}

The RGS treatments significantly stimulated the net photosynthetic rate in the eggplant at its lower two ratios (RGS1 and RGS2) compared with the control (Figure 5A,D), while RGS3 significantly lowered the net photosynthesis rate. Overall, a higher photosynthesis rate was observed at fruiting stages compared with flowering stages during both trials. In 2016, RGS2 showed an increase of $15 \%$, $14 \%, 24 \%$ and $25 \%$ in the net photosynthesis at 1 st flowering, 1st fruiting, 2nd flowering, and 2nd fruiting, respectively, compared with the control CK. Similar trends in results were observed during 2017 (Figure 5A,D). Furthermore, RGS1 and RGS2 treatments enhanced the stomatal conductance, which was highest at the flowering stages (Figure 5E-H). RGS1 and RGS2 inhibited the accumulation of internal $\mathrm{CO}_{2}$ at all stages. The transpiration rates did not vary significantly in RGS1 and RGS2 but decreased in the case of RGS3. Overall, higher transpiration was observed at flowering stages than at fruiting stages (Figure 5M,P).
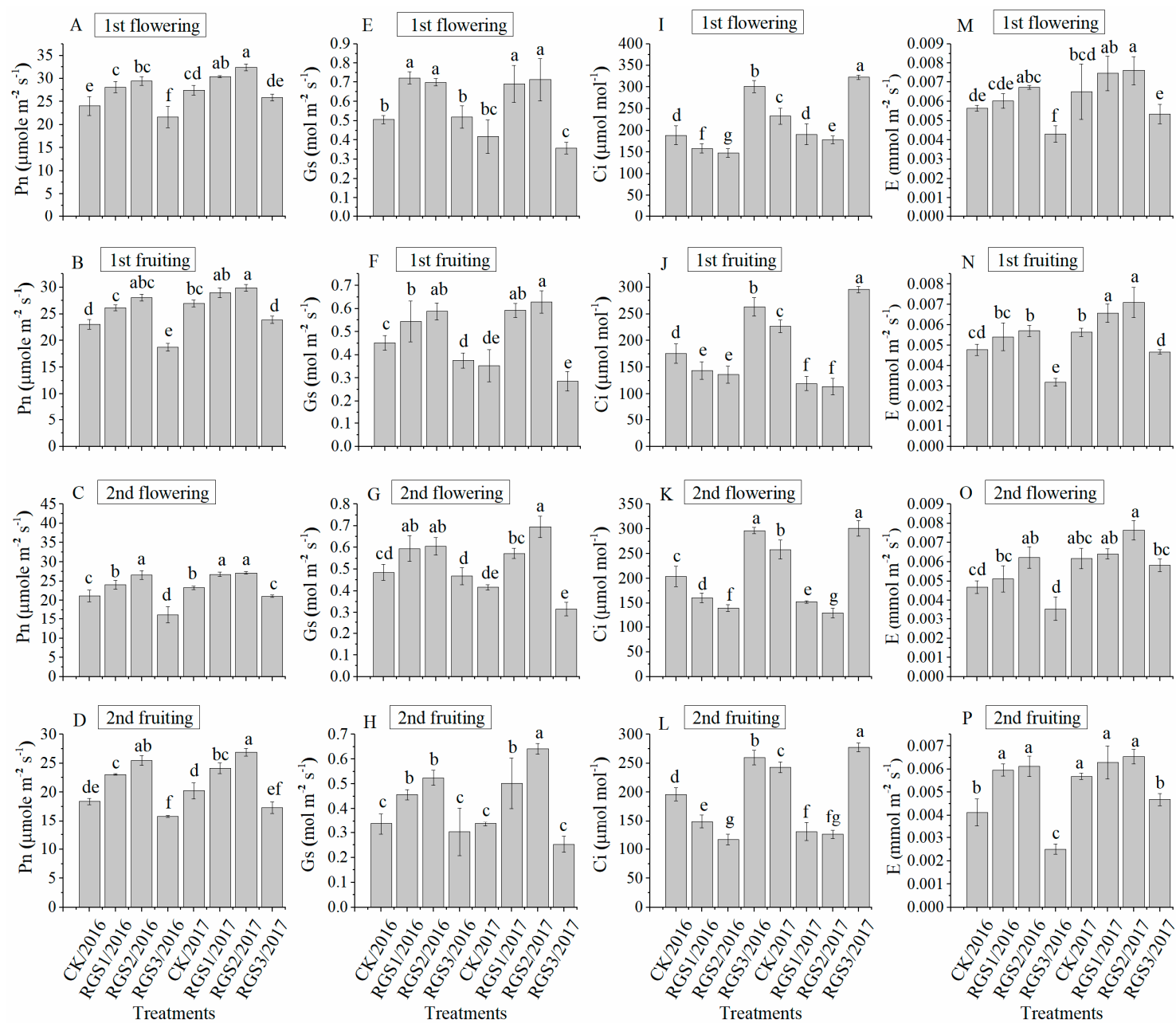

Figure 5. Effect of amendment with raw garlic stalk on different gas exchange parameters of eggplant. Net photosynthesis rate (Pn) (A) 1st flowering, (B) 1st fruiting, (C) 2nd flowering and (D) 2nd fruiting, stomatal conductance (Gs) during (E) 1st flowering, (F) 1st fruiting, (G) 2nd flowering and (H) 2nd fruiting, internal $\mathrm{CO}_{2}(\mathrm{Ci})$ (I) 1st flowering, (J) 1st fruiting, (K) 2nd flowering and (L) 2nd fruiting, transpiration rate (E) (M) 1st flowering, (N) 1st fruiting, (O) 2nd flowering and (P) 2nd fruiting. The error bars represent standard error of the means $(n=3)$. Different letters between treatments at different sampling stages show significant difference at $p<0.05$ level (ANOVA and LSD). 


\subsection{Effect of $\mathrm{RGS}$ on $\mathrm{H}_{2} \mathrm{O}_{2}$ and MDA Contents}

The RGS treatment resulted in an overall decrease in $\mathrm{H}_{2} \mathrm{O}_{2}$ and MDA during both experimental periods (Figure 6A,H). During both years the $\mathrm{H}_{2} \mathrm{O}_{2}$ and MDA contents were significantly lower in RGS1 and RGS2 than in the control CK (Figure 6C,D). Within all growth stages under study, a higher MDA production was observed at the first fruiting (12\% in 2016 and $23 \%$ in 2017) and second fruiting stages (23\% in 2016 and $27 \%$ at 2nd fruiting in 2017). Higher $\mathrm{H}_{2} \mathrm{O}_{2}$ was also observed in RGS3 in both years at the 2nd fruiting stages by 39\% in 2016 and 10\% in 2017. The ratio of RGS1 and RGS2 showed a decreasing trend in all sampling stages in both years (Figure 6E,H).
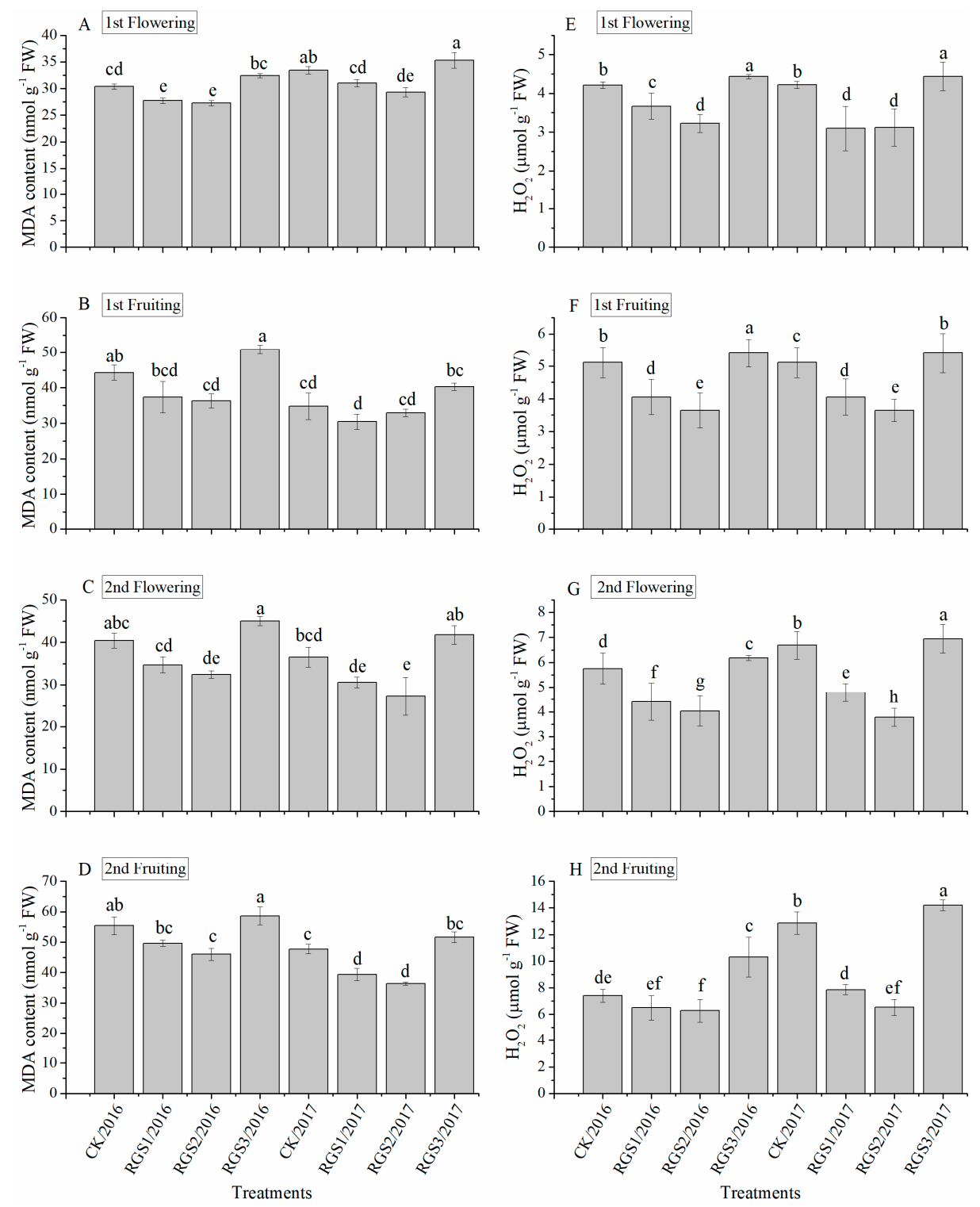

Figure 6. Effect of amendment with raw garlic stalk on plant stress indicators. Malondialdehyde (MDA) (A) 1st flowering, (B) 1st fruiting, (C) 2nd flowering and (D) 2nd fruiting, hydrogen peroxide $\left(\mathrm{H}_{2} \mathrm{O}_{2}\right)$ contents (E) 1st flowering, (F) 1st fruiting, (G) 2nd flowering and ( $\left.\mathbf{H}\right)$ 2nd fruiting. The error bars represent standard error of the means $(n=3)$. Different letters between treatments at different sampling stages show significant difference at $p<0.05$ level (ANOVA and LSD).

\subsection{Antioxidants and Plant Enzyme Activities}

Application of RGS at various doses significantly affected the SOD activity at various growth stages in both years (Figure 7A,D). In 2016 and 2017, SOD activity in RGS1, RGS2 showed an increasing 
trend from the flowering to fruiting stages. It was highest at the 2nd fruiting stage, being $31 \%$ and $34 \%$ higher in 2016 and $27 \%$ and 32\% in 2017 as compared to the control. However, at a higher ratio (RGS3) it was lowered (Figure 7A,D).
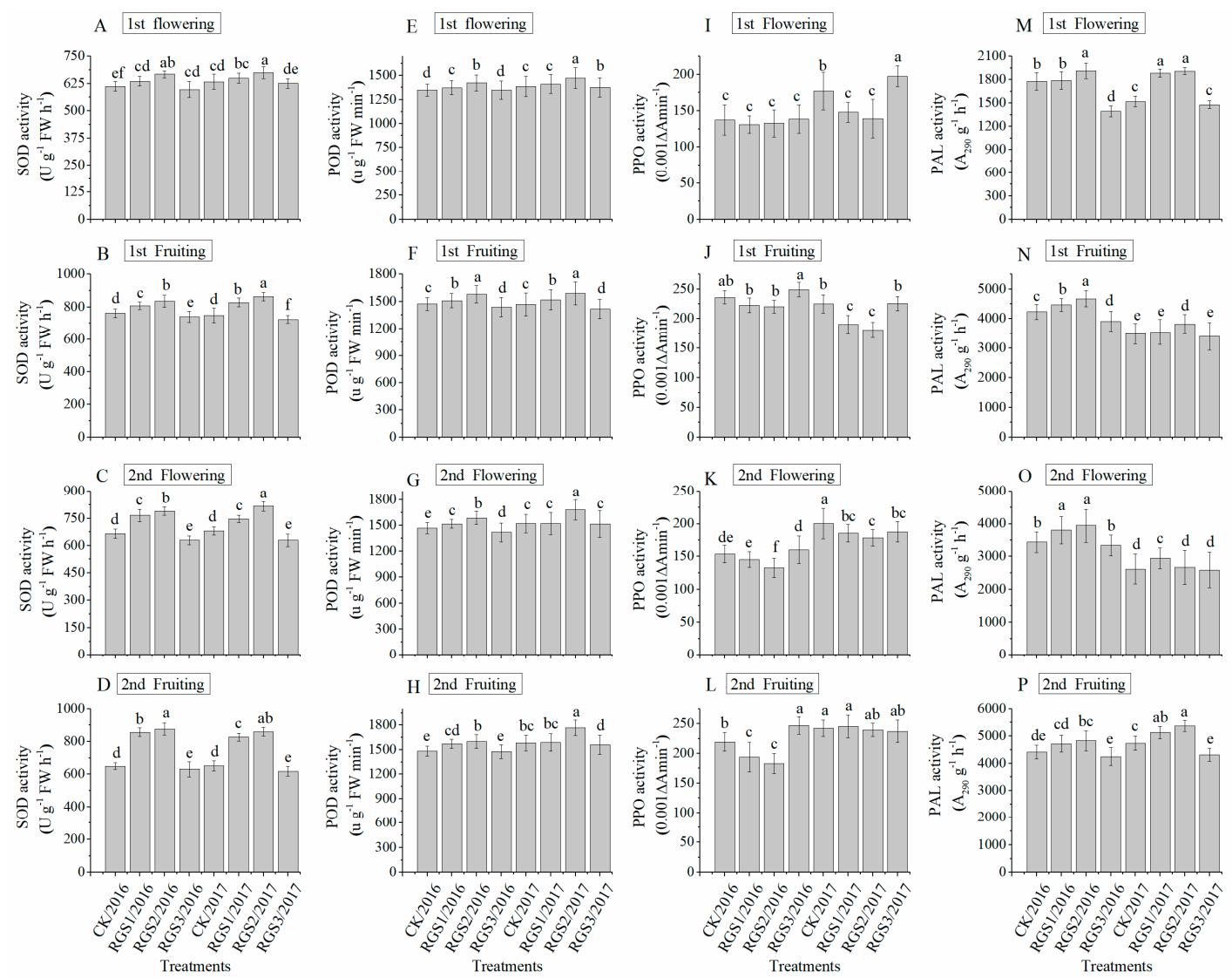

Figure 7. Effect of amendment with raw garlic stalk on superoxide dismutase (SOD) activity (A) 1st flowering, (B) 1st fruiting, (C) 2nd flowering and (D) 2nd fruiting. Peroxidase (POD) activity (E) 1st flowering, (F) 1st fruiting, (G) 2nd flowering and (H) 2nd fruiting. Phenylalanine ammonia-lyase (PAL) activity (I) 1st flowering, (J) 1st fruiting, (K) 2nd flowering and (L) 2nd fruiting. Polyphenol oxidase (PPO) activity (M) 1st flowering, (N) 1st fruiting, (O) 2nd flowering and (P) 2nd fruiting. The error bars represent standard error of the means $(n=3)$. Different letters between treatments at different sampling stages show significant difference at $p<0.05$ level (ANOVA and LSD).

In 2016 and 2017 at different flowering and fruiting stages, the POD activity in all treatments was higher at RGS1 and RGS2 (Figure 7E,H). In 2016, during 1st flowering, the highest POD activity in RGS2 was 5.36\%. Similar trends were also observed in 2017, where at the 1st fruiting the highest POD activity in RGS2 was $6 \%$. Similar trends were observed in both years at the 2 nd flowering stages. The POD activities were also increased in the 2nd fruiting stages in RGS1 and RGS2, being $6 \%$ and 7\% higher as compared to the control in 2016; a similar trend was observed in 2017. In the case of the higher ratio (RGS3), the POD activity was lowered (Figure 7E,H).

Figure 7I,L shows the effect of RGS application on PPO activity in the eggplant leaves during 2016 and 2017. The PPO activity had an inverse relationship with POD. The PPO enzyme activity was higher in CK and higher ratio RGS3 as compared to RGS1 and RGS3 but there is no significant difference in most of the growth stages between the control and RGS treatments, except in 2016 at the 2nd fruiting stage, when PPO activity was 12\% higher in RGS3 as compared to the control (Figure 7I,L).

Application of RGS at all concentrations significantly affected PAL activity (Figure 7G, H). At the 1st flowering, maximum PAL activity was recorded in RGS2 (7\% and 25\%), followed by RGS1 $(0.9 \%$ and $23 \%)$, while in RGS3 the activity reduced ( $21 \%$ and $2 \%$ ) compared with the control in 2016 
and 2017, respectively. A significant increase in PAL activity was observed in RGS2 at first fruiting, 2nd flowering, and 2nd fruiting in 2016 and 2017. The minimum PAL activities were observed in RGS3 in all growth stages in both 2016 and 2017 (Figure 7M,P).

\subsection{Effect of Different RGS Rates on Fusarium wilt and Yield of Eggplant}

The RGS treatments in different concentrations had significant effects on the control of Fusarium wilt disease in eggplant in both the years (Table 5). The disease incidence was reduced in treatments RGS1, RGS2 and RGS3 by $12 \%, 37 \%$ and $62 \%$ in 2016 , and $50 \%, 66 \%$ and $83 \%$ in 2017 respectively, as compared to $\mathrm{CK}$, whereas treatment and year interaction have significant difference. The eggplant fruit yield under the influence of the different ratios of RGS in 2016 and 2017 were enhanced by RGS1 (22\% in 2016 and 22\% in 2017; Figure 8). But the maximum yield was obtained with RGS2 treatment being 58\% and 64\% higher than the control in 2016 and 2017, respectively. The RGS3 treatment had an inhibitory effect and reduced the fruit yield as compared with CK treatment (Figure 8).

Table 5. Effect of different ratios of raw garlic stalk on Fusarium wilt incidence of eggplant during 2016 and 2017.

\begin{tabular}{|c|c|c|c|c|c|c|c|c|c|}
\hline \multirow[b]{2}{*}{ Treatment } & \multicolumn{3}{|c|}{ Number of Infected Plants } & \multicolumn{3}{|c|}{ Disease Incidence (\%) } & \multicolumn{3}{|c|}{ Disease Severity Index } \\
\hline & 2016 & 2017 & Means & 2016 & 2017 & Means & 2016 & 2017 & Means \\
\hline CK & $8.00^{\mathrm{b}}$ & $12.01^{\mathrm{a}}$ & 10.00 & $26.67^{b}$ & $40.06^{\mathrm{a}}$ & 33.36 & $50.33^{a}$ & $51.00^{\mathrm{a}}$ & 50.67 \\
\hline RGS1 & $7.17^{b}$ & $7.00^{b}$ & 7.08 & $23.89 \mathrm{bc}$ & $20.67^{c}$ & 22.28 & $38.00^{\mathrm{b}}$ & $39.00^{\mathrm{b}}$ & 38.50 \\
\hline RGS2 & $5.00^{\mathrm{c}}$ & $4.00^{\mathrm{cd}}$ & 4.50 & $16.67^{\mathrm{d}}$ & $13.33^{\text {de }}$ & 15.00 & $37.67^{\mathrm{b}}$ & $32.00^{c}$ & 34.83 \\
\hline RGS3 & 3.00 de & $2.00^{\mathrm{e}}$ & 2.50 & 10.00 ef & $6.67^{f}$ & 8.33 & $33.00^{c}$ & $31.00^{\mathrm{c}}$ & 32.00 \\
\hline Year means & 5.79 & 6.25 & & 19.31 & 20.18 & & 39.75 & 38.25 & \\
\hline LSD-test & $\underset{* * *}{\text { Treatment }}$ & $\begin{array}{l}\text { Year } \\
\text { NS }\end{array}$ & $\underset{* * *}{\text { Interaction }}$ & $\underset{* * *}{\text { Treatment }}$ & $\begin{array}{l}\text { Year } \\
\text { NS }\end{array}$ & $\underset{* * *}{\text { Interaction }}$ & $\underset{* * *}{\text { Treatment }}$ & $\underset{*}{\text { Year }}$ & $\begin{array}{c}\text { Interaction } \\
*\end{array}$ \\
\hline
\end{tabular}

Total number of plants: 30; Different letters indicate significant differences between means within columns at $p<0.05$ (ANOVA and LSD). ${ }^{*} p<0.05,{ }^{* * *} p<0$. NS: Non-significant.

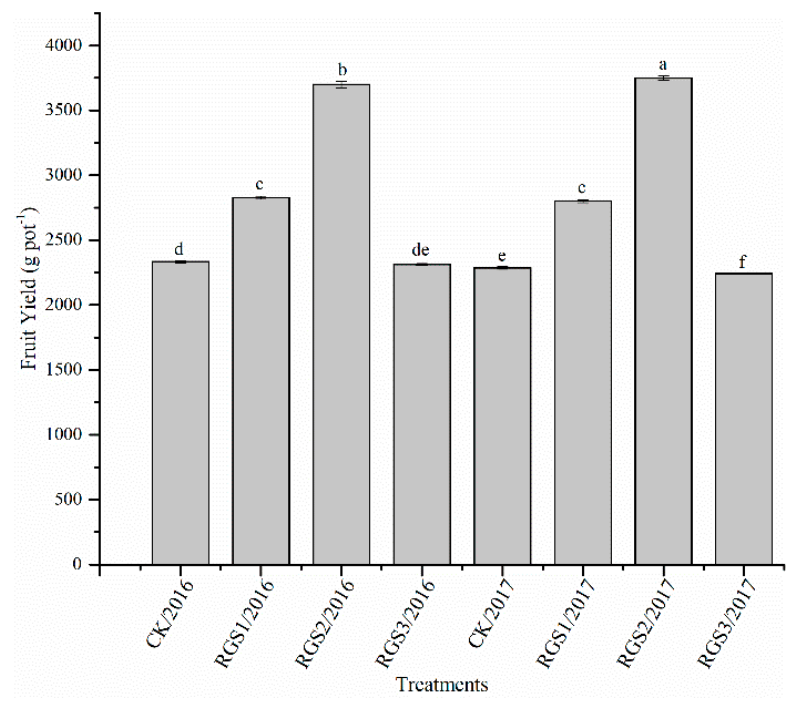

Figure 8. Effect of amendment with raw garlic stalk on fruit yield of eggplant. The error bars represent standard error of the means $(n=3)$. Different letters indicate different means for each treatment two year combination significant difference at $p<0.05$ level (ANOVA and LSD).

\section{Discussion}

\subsection{Effect of RGS on Plant Growth}

Plants exhibit a plethora of phenotypic and physiological changes in response to signals triggered by environmental conditions. These changes are meant to regulate the plant response according to the influence of external signals. In the present study, RGS showed a dose-dependent effect on the 
physiological and morphological responses of the eggplant. Three different doses, i.e., RGS1, RGS2, and RGS3, were applied to eggplant production in pots, where RGS1 is the lowest concentration.

The growth-promoting effect of RGS1 and RGS2 on eggplant in the present study was an indication of the biological stimulatory effect at lower RGS ratios. The application of RGS1 and RGS2 resulted in an increase of different plant growth attributes including plant height, stem diameter, root and shoot weights, leaf area, and root activity (Figures 1-4). The root length was significantly increased by application of RGS1 and RGS2, in addition to enhanced root activity (Figure 4). There are a few studies linking root growth with increased root activity [23]. Garlic is a rich source of enzymes, vitamins (B and $\mathrm{C}$ ), minerals (P, K, Fe, Mn, $\mathrm{Ca}, \mathrm{Na}, \mathrm{Mg}$, and $\mathrm{Zn}$ ), carbohydrates, saponins, alkaloids, flavonoids, free sugars (sucrose, fructose, and glucose), essential amino acids, and traces of iodine [31-33]. This nutritional complex might have promoted the plant growth in the present study; a similar observation was also reported by Wang et al. [20].

The RGS1 and RGS2 in the present study promoted the aboveground biomass, which may be attributed to increased assimilation rates in leaves [6]. Moreover, the RGS during decomposition might have released different kinds of chemicals regulating the indigenous hormonal system affecting plant growth [34,35]. Han et al. [36] also showed that the decomposed garlic stalk, when applied at lower ratios, increased the plant growth and affected the related plant physiological indicators. This positive impact might also be due to improvement in soil nutrient status and soil ecology [36]. Chlorophyll $\mathrm{a}$ and $\mathrm{b}$ are generally regarded as the most vital photosynthetic parameters. An increase in these parameters in plants results in higher photosynthetic rates, as observed in our study of RGS1 and RGS2 (Tables 1-3), similar to previous reports [37]. Maintaining higher chlorophyll contents is important to alleviate abiotic stresses during adverse soil conditions. However, higher doses of RGS inhibited eggplant growth, chlorophyll contents, and most photosynthesis attributes in both years. Garlic reportedly contains organosulfur compounds such as DADS (diallyl disulfides), diallyl trisulfide (DATS), and allicin (strong antioxidants), which at higher concentrations inhibit plant growth and photosynthesis by decreasing chlorophyll contents and root length [38,39]. Similar results were observed in our study in the case of RGS3. Moreover, our findings were also supported by Yu et al. [40].

Carotenoids are very important components that protect the photosynthetic system of plants, particularly in stressed environments, by regulating the chlorophyll contents and reacting with products of lipid peroxidation to stop chain reactions and the generation of free radicals in plants [41].

The maintenance of an optimum photosynthetic rate is an important attribute for plants to survive under stressed environments [42]. The photosynthesis rate also depends on the nitrate assimilation and $\mathrm{CO}_{2}$ fixation [43]. The results of this study also showed significantly higher leaf E, Gs, and Pn but lower Ci at RGS1 and RGS2 as compared with the control (Figure 5). The results showing that carbon dioxide assimilation is inhibited under stress conditions are also in agreement with previous results from Yu et al. [40]. The present results asserted the presence of a threshold RGS concentration to get favorable allelochemical influences. Moreover, the increase in E, Gs, and Pn in RGS improved the gas exchange capacity of eggplant by increasing transpiration fluxes, sustaining stomata, and reducing stomatal resistance.

\subsection{RGS as an Antioxidative Defense Regulator}

During stress conditions, unconstrained ROS production results in oxidative protein and DNA damage [44]. Therefore, the plants scavenge the excessive ROS by activating enzymes such as SOD, POD, PAL, and PPO $[45,46]$. SOD is the first defensive enzyme that rapidly converts $\mathrm{O}_{2}{ }^{-}$into comparatively less toxic $\mathrm{H}_{2} \mathrm{O}_{2}$ [47]. Higher activities of SOD at RGS1 and RGS2 treatments compared to CK treatment, as shown in Figure 7, suggest that the RGS played an important role in stimulation of SOD activity, which prevented the plant from being injured by overproduction of ROS and pathogens. It was also demonstrated in Arabidopsis that SOD played a positive role in the regulation of cell wall biosynthesis and ROS generation, thus improving plant growth [9]. Incorporation of RGS at lower ratios (RGS1 and RGS2) also reduced the overproduction of $\mathrm{H}_{2} \mathrm{O}_{2}$ and hence protected the plant from 
oxidative damage [48]. Though $\mathrm{H}_{2} \mathrm{O}_{2}$ is comparatively less toxic, in excess it also causes severe damage to plants. The results were further confirmed by experiments in the two consecutive years. The growth promotion of eggplant in this study might be due to the regulated production of ROS and antioxidative enzymes, in addition to the spatiotemporal playoff between ROS and other signals [49].

MDA is another indicator of cellular damage resulting from oxidative stress based on the lipid peroxidation [50]. ROS cause decomposition of polyunsaturated fatty acid hydroperoxides and produce MDA [51]. MDA, being a highly reactive aldehyde, disrupts cell processes by making bonds with proteins and nucleic acid, forming insoluble compounds and hence influencing normal plant growth and development [52]. The lower MDA content (Figure 6) in our study revealed that RGS could improve the plant's ability to survive stress conditions and hence improved the plant productivity. Additionally, higher ratios of RGS inhibited the growth and enhanced the MDA contents, indicating lipid peroxidation of the membrane. Due to the oxidative nature of RGS, the eggplant may undergo oxidative stress, resulting in higher MDA content due to cellular damage [53]. In addition, ROS also caused lipid peroxidation and cell damage, leading to an abundance of MDA [54].

The triggering of physiological metabolism and enhanced defense enzymes in eggplant upon treatment with RGS also indicates a priming phenomenon for yield production, as previously shown in cabbages [55]. Moreover, overproduction of SOD has been reported as a plant growth promoter under salt stress conditions [56]. These reports are strongly coherent with our present study.

PPO and POD play a very important role in plant defense systems by acting synergistically. PPO stimulates $\mathrm{H}_{2} \mathrm{O}_{2}$ generation from oxidation of phenolic compounds $[57,58]$. These enzymes produce quinones by oxidizing phenolic compounds, which are toxic to insect pests and pathogens. These quinones produce colored compounds by non-enzymatic covalent with proteins and carbohydrates, which act as a barrier against biotic and abiotic stresses [59]. PPO catalyzes the polymerization of phenolics and the formation of lignin and flavonoids by the phenylpropanoid biosynthetic pathway, thus enhancing the plant's defense against invading pathogens by the formation of defense barriers $[59,60]$.

POD could transform $\mathrm{H}_{2} \mathrm{O}_{2}$ into $\mathrm{H}_{2} \mathrm{O}$ by utilizing a variety of electron donors. Moreover, it plays an important role in plant defense systems during various kinds of biotic and abiotic stresses [61,62]. The negative correlation between $\mathrm{POD}$ activity and $\mathrm{H}_{2} \mathrm{O}_{2}$ concentration indicates its role in scavenging excess $\mathrm{H}_{2} \mathrm{O}_{2}$. A previous investigation [63] revealed that POD inhibits the activity of PPO, confirming the trends of our experiment (lower PPO activity means higher PDO activity and vice versa).

The PAL activity is of prime importance, contributing to plants' potential to survive adverse conditions. PAL increases the lignification of plant cells. In this experiment, PAL activity in the RGS1 and RGS2 treatments was higher than in the CK treatment (Figure 7), which may cause higher lignification and stronger and more resistant plants in the RGS1 and RGS2 treatments, resulting in higher plant growth and yield. As in the previous study of Moller et al. [64], higher PAL activity was seen in lignified cells, while no activity was detected in non-lignified cells. The higher activity of PAL in both RGS1 and RGS2 showed that RGS, when used at appropriate levels, may protect the plant from invading pests and pathogens.

\subsection{Effect of RGS on Fusarium wilt and Yield of Eggplant}

Eggplant faces continuous cropping obstacles such as reductions in crop quality, aggravation of soil-borne disease, and yield decline under plastic tunnel cultivation. Fusarium wilt caused by Fusarium oxysporum (Schl.) f. sp. melongenae is a fungal soil-borne disease that causes a significant reduction in eggplant yield [65]. Use of fungicides may adversely affect the environment. Amendment of soil with organic residue is used not only to control soil-born nematodes but also other soil-borne diseases [66]. Decomposition of organic materials in the soil can create anaerobic conditions and produce metabolites that are capable of killing pathogens or immobilizing their activity [67]. In our study, application of RGS showed dual effects with different concentrations; it reduced the incidence of Fusarium wilt in all the treatments (Table 5), whereas it reduced yield at higher concentrations of 
the applied RGS (Figure 8). Earlier studies partially confirmed our results that a higher concentration of garlic straw (4\%) reduced nematode incidence in tomatoes but caused a reduction in yield [68]. This might be due to the release of allelochemicals during garlic stalk decomposition. The higher dose of RGS in the soil might also have increased the microbial population, leading to a slow decomposition rate due to a higher $\mathrm{C}: \mathrm{N}$ ratio after the amendment. Our results are in line with a previous study [69].

\section{Conclusions}

The present investigation reflected the dose-dependent activity of RGS as a plant growth and defense stimulator for eggplant cultivation. The application of RGS to soil at lower ratios promoted the growth and development of eggplant and, hence, increased the yield. Furthermore, it regulated the antioxidant plant defense system, which ensured better plant survival under stress. However, more efforts are needed in the future, before it can be used in environmental safety strategies, to verify the effect of RGS addition to soil in real agroecosystems (i.e., open field conditions, real crop rotation).

Author Contributions: Conceptualization, M.I.G., Z.C. methodology, A.A.; writing—original draft preparation, M.I.G., M.J.A; writing-review and editing, Z.C., M.A. (Muhammad Ali), M.A. (Muhammad Anees), B.A.

Funding: This research was funded by Shaanxi Provincial Sci Tech Innovation Plan (grant number 2016KTCL02-01), Shaanxi provincial Agricultural Sci Tech Innovation and Development Plan (grant number 2016NY-048) and Xian City Agricultural Sci Tech Innovation Plan P.R China, grant number NCI 1501.

Conflicts of Interest: The authors declare no conflict of interest.

\section{References}

1. Sarrantonio, M.; Gallandt, E. The role of cover crops in North American cropping systems. J. Crop Prod. 2003, 8, 53-74. [CrossRef]

2. Gupta, R.; Ladha, J. Placement effects on rice residue decomposition and nutrient dynamics on two soil types during wheat cropping in rice-wheat system in northwestern India. Nutr. Cycl. Agroecosyst. 2010, 88, 471-480.

3. Ilieva-Makulec, K.; Olejniczak, I.; Szanser, M. Response of soil micro-and mesofauna to diversity and quality of plant litter. Eur. J. Soil Biol. 2006, 42, S244-S249. [CrossRef]

4. DuPont, S.T.; Ferris, H.; Van Horn, M. Effects of cover crop quality and quantity on nematode-based soil food webs and nutrient cycling. Appl. Soil Ecol. 2009, 41, 157-167. [CrossRef]

5. Tian, Y.; Liu, J.; Zhang, X.; Gao, L. Effects of summer catch crop, residue management, soil temperature and water on the succeeding cucumber rhizosphere nitrogen mineralization in intensive production systems. Nutr. Cycl. Agroecosyst. 2010, 88, 429-446. [CrossRef]

6. Xiao, X.; Cheng, Z.; Meng, H.; Khan, M.A.; Li, H. Intercropping with garlic alleviated continuous cropping obstacle of cucumber in plastic tunnel. Acta Agric. Scand. B Soil Plant Sci. 2012, 62, 696-705. [CrossRef]

7. Wang, M.; Wu, C.; Cheng, Z.; Meng, H. Growth and physiological changes in continuously cropped eggplant (Solanum melongena L.) upon relay intercropping with garlic (Allium sativum L.). Front. Plant Sci. 2015, 6, 262. [CrossRef] [PubMed]

8. Chen, S.; Zhou, B.; Lin, S.; Li, X.; Ye, X. Accumulation of cinnamic acid and vanillin in eggplant root exudates and the relationship with continuous cropping obstacle. Afr. J. Biotechnol. 2011, 10, 2659-2665.

9. Safikhani, N.; Morid, B.; Zamanizadeh, H. First report of Fusarium wilt of eggplant caused by Fusarium oxysporum f. sp. melongenae in Iran. New Dis. Rep. 2013, 28. [CrossRef]

10. Asada, K. Production and scavenging of reactive oxygen species in chloroplasts and their functions. Plant Physiol. 2006, 141, 391-396. [CrossRef]

11. Sharma, P.; Jha, A.B.; Dubey, R.S.; Pessarakli, M. Reactive oxygen species, oxidative damage, and antioxidative defense mechanism in plants under stressful conditions. J. Bot. 2012, 2012. [CrossRef]

12. Noctor, G.; Veljovic-Jovanovic, S.; Driscoll, S.; Novitskaya, L.; Foyer, C.H. Drought and oxidative load in the leaves of C3 plants: A predominant role for photorespiration? Ann. Bot. 2002, 89, 841-850. [CrossRef] [PubMed] 
13. Tanou, G.; Molassiotis, A.; Diamantidis, G. Hydrogen peroxide-and nitric oxide-induced systemic antioxidant prime-like activity under $\mathrm{NaCl}$-stress and stress-free conditions in citrus plants. J. Plant Physiol. 2009, 166, 1904-1913. [CrossRef] [PubMed]

14. Bright, J.; Desikan, R.; Hancock, J.T.; Weir, I.S.; Neill, S.J. ABA-induced NO generation and stomatal closure in Arabidopsis are dependent on $\mathrm{H}_{2} \mathrm{O}_{2}$ synthesis. Plant J. 2006, 45, 113-122. [CrossRef] [PubMed]

15. Peng, C.; Ou, Z.; Liu, N.; Lin, G. Response to high temperature in flag leaves of super high-yielding rice Pei'ai 64S/E32 and Liangyoupeijiu. Rice Sci. 2005, 12, 179-186.

16. Yin, X.M.; Huang, L.F.; Zhang, X.; Wang, M.L.; Xu, G.Y.; Xia, X.J. OsCML4 improves drought tolerance through scavenging of reactive oxygen species in rice. J. Plant Biol. 2015, 58, 68-73. [CrossRef]

17. Suleman, P.; Redha, A.; Afzal, M.; Al-Hasan, R. Temperature-induced changes of malondialdehyde, heat-shock proteins in relation to chlorophyll fluorescence and photosynthesis in Conocarpus lancifolius (Engl.). Acta Physiol. Plant. 2013, 35, 1223-1231. [CrossRef]

18. Meloni, D.A.; Oliva, M.A.; Martinez, C.A.; Cambraia, J. Photosynthesis and activity of superoxide dismutase, peroxidase and glutathione reductase in cotton under salt stress. Environ. Exp. Bot. 2003, 49, 69-76. [CrossRef]

19. Choi, I.-H.; Shin, S.-C.; Park, I.-K. Nematicidal activity of onion (Allium cepa) oil and its components against the pine wood nematode (Bursaphelenchus xylophilus). Nematology 2007, 9, 231-235.

20. Wang, M.; Wu, C.; Cheng, Z.; Meng, H.; Zhang, M.; Zhang, H. Soil chemical property changes in eggplant/garlic relay intercropping systems under continuous cropping. PLoS ONE 2014, 9, e111040. [CrossRef]

21. Cheng, Z.-H.; Jin, R.; Tong, F. Study on Allelopathic Effect of Garlic Plant Volatile on Cucumber Seedling Growth. Acta Agric. Boreali-Occident. Sin. 2007, 3, 037.

22. Abràmoff, M.D.; Magalhães, P.J.; Ram, S.J. Image processing with ImageJ. Biophotonics Int. 2004, 11, 36-42.

23. Lariguet, P.; Ranocha, P.; De Meyer, M.; Barbier, O.; Penel, C.; Dunand, C. Identification of a hydrogen peroxide signalling pathway in the control of light-dependent germination in Arabidopsis. Planta 2013, 238, 381-395. [CrossRef] [PubMed]

24. Arnon, D.I. Copper enzymes in isolated chloroplasts. Polyphenoloxidase in Beta vulgaris. Plant Physiol. 1949, 24, 1. [CrossRef]

25. Distefano, G.; La Malfa, S.; Vitale, A.; Lorito, M.; Deng, Z.; Gentile, A. Defence-related gene expression in transgenic lemon plants producing an antimicrobial Trichoderma harzianum endochitinase during fungal infection. Transgenic Res. 2008, 17, 873-879. [CrossRef] [PubMed]

26. Zhang, Z.; Qu, W. The Guidance of Plant Physiology Experiments; Chinese Agricultural Science and Technology Press: Beijing, China, 2004.

27. Gao, J. Experimental Guidance for Plant Physiology; China Higher Education Press: Beijing, China, 2006.

28. Bestwick, C.S.; Brown, I.R.; Mansfield, J.W. Localized changes in peroxidase activity accompany hydrogen peroxide generation during the development of a nonhost hypersensitive reaction in lettuce. Plant Physiol. 1998, 118, 1067-1078. [CrossRef] [PubMed]

29. Zheng, L.; Zhong, G.; Zhang, S. PPO activity determination and anti-browning measure for amorphophallus albus. Chin. J. Southwest Univ. (Nat. Sci. Ed.) 2007, 29, 118-121.

30. Wang, W.; Wang, H.; Feng, Y.; Wang, L.; Xiao, X.; Xi, Y.; Luo, X.; Sun, R.; Ye, X.; Huang, Y. Consistent responses of the microbial community structure to organic farming along the middle and lower reaches of the Yangtze River. Sci. Rep. 2016, 6, 35046. [CrossRef]

31. Corzo-Martínez, M.; Corzo, N.; Villamiel, M. Biological properties of onions and garlic. Trends Food Sci. Technol. 2007, 18, 609-625. [CrossRef]

32. Hafez, O.M.; Saleh, M.A.; El-Lethy, S.R. Response of some seedlings olive cultivars to foliar spray of yeast and garlic extracts with or without vascular arbuscular mycorrhizal fungi. J. World Appl. Sci. 2013, 24, 1119-1129.

33. Lanzotti, V. The analysis of onion and garlic. J. Chromatogr. A 2006, 1112, 3-22. [CrossRef] [PubMed]

34. Gruhlke, M.C.; Hemmis, B.; Noll, U.; Wagner, R.; Lühring, H.; Slusarenko, A.J. The defense substance allicin from garlic permeabilizes membranes of Beta vulgaris, Rhoeo discolor, Chara corallina and artificial lipid bilayers. Biochim. Biophys. Acta (BBA)-Gen. Subj. 2015, 1850, 602-611. [CrossRef] [PubMed] 
35. Oracz, K.; Voegele, A.; Tarkowská, D.; Jacquemoud, D.; Turečková, V.; Urbanová, T.; Strnad, M.; Sliwinska, E.; Leubner-Metzger, G. Myrigalone A inhibits Lepidium sativum seed germination by interference with gibberellin metabolism and apoplastic superoxide production required for embryo extension growth and endosperm rupture. Plant Cell Physiol. 2011, 53, 81-95. [CrossRef] [PubMed]

36. Han, X.; Cheng, Z.; Meng, H.; Yang, X.; Ahmad, I. Allelopathic effect of decomposed garlic (Allium sativum L.) stalk on lettuce (L. sativa var. crispa L.). Pak. J. Bot. 2013, 45, 225-233.

37. Masclaux, C.; Valadier, M.-H.; Brugière, N.; Morot-Gaudry, J.-F.; Hirel, B. Characterization of the sink/source transition in tobacco (Nicotiana tabacum L.) shoots in relation to nitrogen management and leaf senescence. Planta 2000, 211, 510-518. [CrossRef] [PubMed]

38. Borlinghaus, J.; Albrecht, F.; Gruhlke, M.C.; Nwachukwu, I.D.; Slusarenko, A.J. Allicin: Chemistry and biological properties. Molecules 2014, 19, 12591-12618. [CrossRef] [PubMed]

39. Cheng, F.; Cheng, Z.; Meng, H.; Tang, X. The garlic allelochemical diallyl disulfide affects tomato root growth by influencing cell division, phytohormone balance and expansin gene expression. Front. Plant Sci. 2016, 7, 1199. [CrossRef]

40. Yu, B.; Zhang, D.; Huang, C.; Qian, M.; Zheng, X.; Teng, Y.; Su, J.; Shu, Q. Isolation of anthocyanin biosynthetic genes in red Chinese sand pear (Pyrus pyrifolia Nakai) and their expression as affected by organ/tissue, cultivar, bagging and fruit side. Sci. Hortic. 2012, 136, 29-37. [CrossRef]

41. Yoshii, H.; Yoshii, Y.; Asai, T.; Furukawa, T.; Takaichi, S.; Fujibayashi, Y. Photo-excitation of carotenoids causes cytotoxicity via singlet oxygen production. Biochem. Biophys. Res. Commun. 2012, 417, 640-645. [CrossRef]

42. Krasylenko, Y.A.; Yemets, A.I.; Sheremet, Y.A.; Blume, Y.B. Nitric oxide as a critical factor for perception of UV-B irradiation by microtubules in Arabidopsis. Physiol. Plant. 2012, 145, 505-515. [CrossRef]

43. Yang, Y.; Han, X.; Liang, Y.; Ghosh, A.; Chen, J.; Tang, M. The combined effects of arbuscular mycorrhizal fungi (AMF) and lead $(\mathrm{Pb})$ stress on $\mathrm{Pb}$ accumulation, plant growth parameters, photosynthesis, and antioxidant enzymes in Robinia pseudoacacia L. PLoS ONE 2015, 10, e0145726. [CrossRef] [PubMed]

44. Das, K.; Roychoudhury, A. Reactive oxygen species (ROS) and response of antioxidants as ROS-scavengers during environmental stress in plants. Front. Environ. Sci. 2014, 2, 53. [CrossRef]

45. Liu, Z.; Wang, X. Changes in color, antioxidant, and free radical scavenging enzyme activity of mushrooms under high oxygen modified atmospheres. Postharvest Biol. Technol. 2012, 69, 1-6. [CrossRef]

46. Rai, A.C.; Singh, M.; Shah, K. Effect of water withdrawal on formation of free radical, proline accumulation and activities of antioxidant enzymes in ZAT12-transformed transgenic tomato plants. Plant Physiol. Biochem. 2012, 61, 108-114.

47. Hasan, S.A.; Fariduddin, Q.; Ali, B.; Hayat, S.; Ahmad, A. Cadmium: Toxicity and tolerance in plants. J. Environ. Biol. 2009, 30, 165-174. [PubMed]

48. Li, Y.; Zhang, S.; Jiang, W.; Liu, D. Cadmium accumulation, activities of antioxidant enzymes, and malondialdehyde (MDA) content in Pistia stratiotes L. Environ. Sci. Pollut. Res. 2013, 20, 1117-1123. [CrossRef] [PubMed]

49. Baxter, A.; Mittler, R.; Suzuki, N. ROS as key players in plant stress signalling. J. Exp. Bot. 2013, 65, 1229-1240. [CrossRef] [PubMed]

50. Del Rio, D.; Stewart, A.J.; Pellegrini, N. A review of recent studies on malondialdehyde as toxic molecule and biological marker of oxidative stress. Nutr. Metab. Cardiovasc. Dis. 2005, 15, 316-328. [CrossRef]

51. Tommasino, E.; Griffa, S.; Grunberg, K.; Ribotta, A.; Colomba, E.L.; Carloni, E.; Quiroga, M.; Luna, C.M. Malondialdehyde content as a potential biochemical indicator of tolerant Cenchrus ciliaris L. genotypes under heat stress treatment. Grass Forage Sci. 2012, 67, 456-459. [CrossRef]

52. Huang, G.-T.; Ma, S.-L.; Bai, L.-P.; Zhang, L.; Ma, H.; Jia, P.; Liu, J.; Zhong, M.; Guo, Z.-F. Signal transduction during cold, salt, and drought stresses in plants. Mol. Biol. Rep. 2012, 39, 969-987. [CrossRef]

53. Gill, S.S.; Tuteja, N. Reactive oxygen species and antioxidant machinery in abiotic stress tolerance in crop plants. Plant Physiol. Biochem. 2010, 48, 909-930. [CrossRef]

54. Hirt, H.; Shinozaki, K. Plant Responses to Abiotic Stress; Springer Science \& Business Media: Berlin, Germany, 2003; Volume 4.

55. Yiu, J.-C.; Tseng, M.-J. Manipulation of superoxide dismutase and catalase to enhance sulfur dioxide tolerance in transgenic Chinese cabbage. In II International Symposium on Biotechnology of Tropical and Subtropical Species 692; International Society for Horticultural Science: Taipei, Taiwan, 2001; pp. 91-100. 
56. Shafi, A.; Chauhan, R.; Gill, T.; Swarnkar, M.K.; Sreenivasulu, Y.; Kumar, S.; Kumar, N.; Shankar, R.; Ahuja, P.S.; Singh, A.K. Expression of SOD and APX genes positively regulates secondary cell wall biosynthesis and promotes plant growth and yield in Arabidopsis under salt stress. Plant Mol. Biol. 2015, 87, 615-631. [CrossRef] [PubMed]

57. Tomás-Barberán, F.A.; Espín, J.C. Phenolic compounds and related enzymes as determinants of quality in fruits and vegetables. J. Sci. Food Agric. 2001, 81, 853-876. [CrossRef]

58. Criado, M.; Civera, M.; Martínez, A.; Rodrigo, D. Use of Weibull distribution to quantify the antioxidant effect of Stevia rebaudiana on oxidative enzymes. LWT-Food Sci. Technol. 2015, 60, 985-989. [CrossRef]

59. Constabel, C.P.; Barbehenn, R. Defensive roles of polyphenol oxidase in plants. In Induced Plant Resistance to Herbivory; Springer: Berlin, Germany, 2008; pp. 253-270.

60. Thilagavathi, R.; Saravanakumar, D.; Ragupathi, N.; Samiyappan, R. A combination of biocontrol agents improves the management of dry root rot (Macrophomina phaseolina) in greengram. Phytopathol. Mediterr. 2007, 46, 157-167.

61. Tarchoune, I.; Sgherri, C.; Izzo, R.; Lachaal, M.; Ouerghi, Z.; Navari-Izzo, F. Antioxidative responses of Ocimum basilicum to sodium chloride or sodium sulphate salinization. Plant Physiol. Biochem. 2010, 48, 772-777. [CrossRef]

62. Xue, Y.J.; Tao, L.; Yang, Z.M. Aluminum-induced cell wall peroxidase activity and lignin synthesis are differentially regulated by jasmonate and nitric oxide. J. Agric. Food Chem. 2008, 56, 9676-9684. [CrossRef] [PubMed]

63. Shinshi, H.; Noguchi, M. Relationships between peroxidase, IAA oxidase and polyphenol oxidase. Phytochemistry 1975, 14, 1255-1258. [CrossRef]

64. Möller, R.; Koch, G.; Nanayakkara, B.; Schmitt, U. Lignification in cell cultures of Pinus radiata: Activities of enzymes and lignin topochemistry. Tree Physiol. 2006, 26, 201-210. [CrossRef]

65. Chakraborty, M.; Chatterjee, N.; Quimio, T. Integrated management of fusarial wilt of eggplant (Solanum melongena) with soil solarization. Micol. Apl. Int. 2009, 21, 23-26.

66. Oka, Y. Mechanisms of nematode suppression by organic soil amendments-A review. Appl. Soil Ecol. 2010, 44, 101-115. [CrossRef]

67. Alabouvette, C.; Olivain, C.; Steinberg, C. Biological control of plant diseases: The European situation. Eur. J. Plant Pathol. 2006, 114, 329-341. [CrossRef]

68. Gong, B.; Bloszies, S.; Li, X.; Wei, M.; Yang, F.; Shi, Q.; Wang, X. Efficacy of garlic straw application against root-knot nematodes on tomato. Sci. Hortic. 2013, 161, 49-57. [CrossRef]

69. Sial, T.A.; Khan, M.N.; Lan, Z.; Kumbhar, F.; Zhao, Y.; Zhang, J.; Sun, D.; Xiu, L. Contrasting effects of banana peels waste and its biochar on greenhouse gas emissions and soil biochemical properties. Process Saf. Environ. Prot. 2018, 122, 366-377. [CrossRef]

(C) 2019 by the authors. Licensee MDPI, Basel, Switzerland. This article is an open access article distributed under the terms and conditions of the Creative Commons Attribution (CC BY) license (http://creativecommons.org/licenses/by/4.0/). 